\title{
LA CORRESPONDENCIA ENTRE FELIPE IV Y SOR MARÍA DE ÁGREDA: LECTURA E INTERPRETACIÓN A LA LUZ DE EMPRESAS POLÍTICAS DE SAAVEDRA FAJARDO
}

\author{
José Javier Azanza
}

Universidad de Navarra

RESUMEN: Entre 1643 y 1665 se estableció una fecunda relación epistolar entre Felipe IV y sor María Jesús de Ágreda, en la cual el monarca plasma sus pensamientos sobre política interior y exterior, reflexionando acerca de las principales virtudes que deben adornar al príncipe, su concepto del gobierno del Estado en sus relaciones con los ministros, los consejos y el valido, el conocimiento y trato de sus súbditos, su comportamiento con las potencias europeas en tiempos de paz y de guerra, o su confianza en la voluntad divina que sustenta la monarquía hispana conforme a un marcado providencialismo. Este trabajo pretende establecer los puntos de contacto existentes entre las Empresas políticas (1640) de Diego Saavedra Fajardo y los planteamientos filipinos contenidos en las cartas, y determinar en qué medida pudieron influir las teorías del diplomático murciano en un monarca que actuó como verdadero príncipe políticocristiano.

Palabras clave: Felipe IV, María Jesús de Ágreda, Diego Saavedra Fajardo, España, siglo XviI.

AвSTRACT: Between 1643 and 1665 Philip IV and Sister María Jesús de Ágreda maintained a fertile epistolary exchange, in which the monarch manifested his thoughts on domestic and international politics, reflecting on the principal virtues that should embellish the prince, his concept of the governance of state in his relations with his ministres, the issue of counsel and the royal favourite, the acquaintance of and dealings with his subjects, his comportment towards European potentates in times of war and peace, or his trust in divine will, which sustained the Hispanic Monarchy in accordance with his strong belief of providentialism. This 
paper attempts to establish the points of contact between the Empresas politicas (1640) of Diego Saavedra Fajardo and the ideas espoused by the king in his letters to Sister María, and to determine to what extent the theories of the diplomat and emblematist may have influenced a monarch who acted as a true political and Christian prince.

Keywords: Philip IV, María Jesús de Ágreda, Diego Saavedra Fajardo, Spain, 17th Century.

\section{INTRODUCCIÓN}

«Pasó por este lugar y entró en nuestro convento el Rey nuestro señor, a 10 de julio de 1643, y dejóme mandado que le escribiese...». Con estas palabras encabeza sor María Jesús de Ágreda su correspondencia con Felipe IV, inaugurando una fecunda relación epistolar de más de seiscientas cartas entrecruzadas que constituye una fuente histórica excepcional para el conocimiento de la política española del siglo xVII, y que tan solo se verá interrumpida a la muerte de la religiosa el 24 de mayo de $1665 .{ }^{1}$ Durante todo este tiempo, el monarca plasma sus pensamientos sobre política interior y exterior, reflexionando acerca de las principales virtudes que deben adornar al príncipe, su concepto de gobierno del Estado en sus relaciones con los ministros, los consejos y el valido, el conocimiento y trato de sus súbditos, su comportamiento con las potencias europeas en tiempos de paz y de guerra, o su confianza en la voluntad divina que sustenta la monarquía hispana conforme a un marcado providencialismo político.

Muchas de las pautas de comportamiento de Felipe IV obedecen al sistema de gobierno tradicional de los Austrias. Sin embargo, se nos antoja necesario recordar que apenas tres años antes de la visita del rey al convento soriano había visto la luz en la imprenta de Nicolao Enrico, en Múnich, la editio princeps de las Empresas políticas del diplomático murciano Diego Saavedra Fajardo

1. Sobre las cartas de sor María a Felipe IV, véase Francisco Silvela: Cartas de la Venerable Madre Sor María de Ágreda y del Señor Rey Felipe IV, Sucesores de Rivadeneyra, Madrid, 1885; Epistolario español, vol. v. Cartas de sor María de Jesús de Ágreda y de Felipe IV (edición y estudio preliminar de Carlos Seco Serrano), Atlas, Madrid, 1958; y Correspondencia con Felipe IV: religión y razón de estado (introducción de Consolación Baranda), Castalia, Madrid, 1991. Más recientemente analiza las características, contenido y estilo de las cartas cruzadas entre el rey y la religiosa AnA Morte Acín, Misticismo y conspiración. Sor María de Ágreda en el reinado de Felipe IV, Institución Fernando el Católico, Zaragoza, 2010, pp. 246-266 y 293-407. 


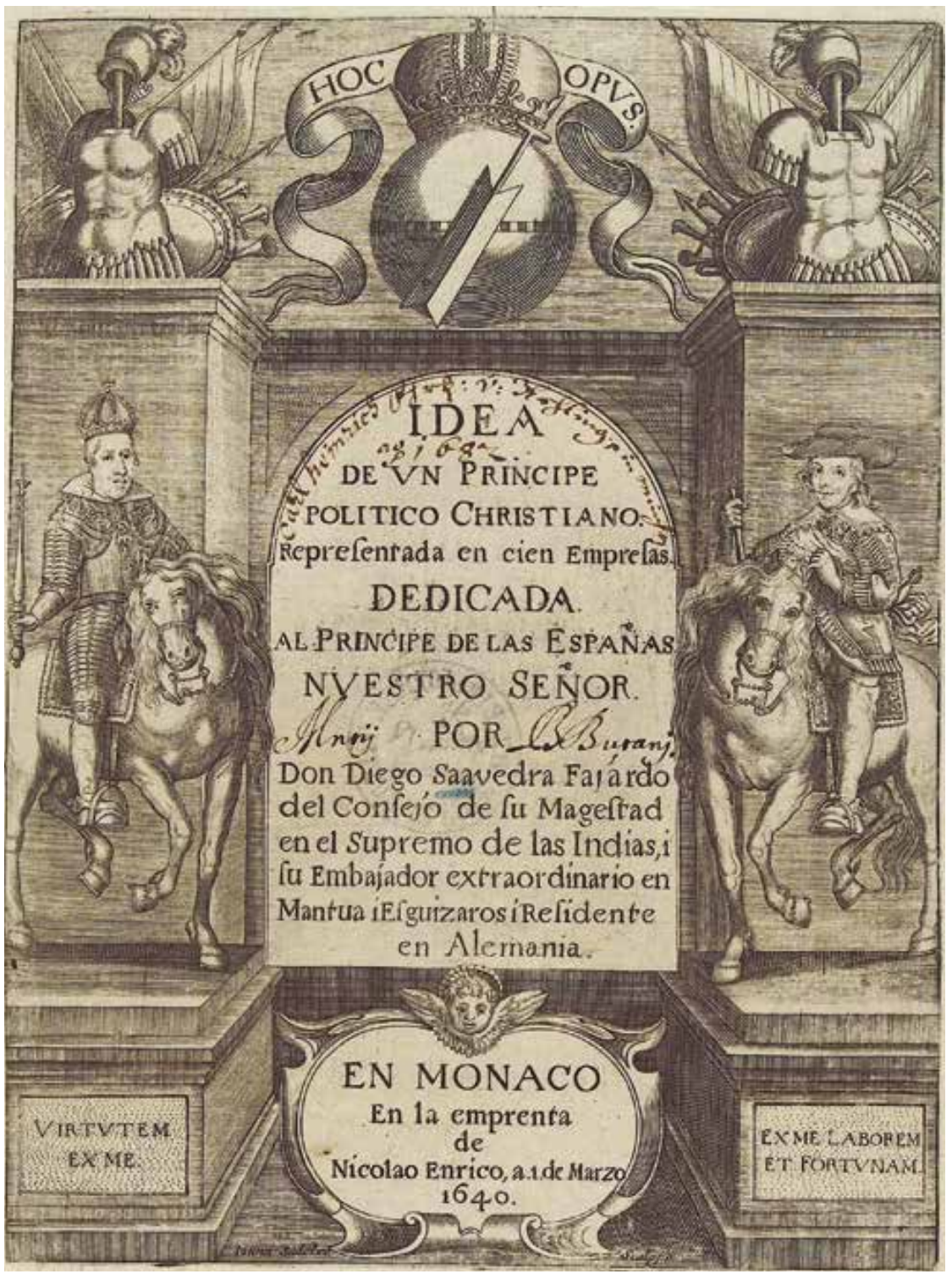

Fig. 1. Diego Saavedra Fajardo. Idea de un principe politico christiano. Portada (1640) 
(la segunda lo haría en Milán en 1642), ${ }^{2}$ obra encaminada a la formación del príncipe Baltasar Carlos que sin duda su padre, hombre culto e intelectual, tuvo que conocer. ${ }^{3}$ Es más, el propio Felipe IV aparecía representado en la portada de la obra [Fig. 1], montado a caballo, ataviado con armadura y con los atributos de rey -corona y cetro-, a los que se suma el toisón de oro sobre el pecho; el segundo jinete del frontispicio es el cardenal infante don Fernando de Austria, hermano del monarca y tío paterno del príncipe. ${ }^{4}$ Es nuestro propósito establecer los puntos de contacto existentes entre las empresas saavedrianas y los planteamientos filipinos contenidos en las cartas, y tratar de determinar en qué medida pudieron influir las teorías de aquel en un monarca que actuó como verdadero príncipe político-cristiano. ${ }^{5}$

\section{UNA MONARQUÍA PROVIDENCIALISTA}

La concepción providencialista de la monarquía española viene del hecho de que goza de la protección de Dios; así se pone de manifiesto en multitud de ocasiones a lo largo de este período, desde proclamas como la aprobada por

2. Como demuestra S. López Poza, existen notables diferencias entre la primera y la segunda edición, convirtiéndose esta última en editio optima para posteriores reediciones. SAgrario López Poza: «Variantes en las dos portadas y en las picturae de las dos versiones de las Empresas políticas de Saavedra Fajardo», en Víctor Mínguez (ed.): Del libro de emblemas a la ciudad simbólica, Vol. II, Publicacions de la Universitat Jaume I, Castelló de la Plana, 2000, pp. 621-646. En nuestro trabajo hemos seguido la segunda edición, si bien nos servimos de la primera para las ilustraciones, salidas del taller de los Sadeler, dada su mayor claridad compositiva y calidad estética. Tan solo en aquellos casos en los que se produce un cambio en el mote o pictura, o la empresa es de nueva creación, utilizamos la edición de Ámsterdam de 1659, cuyas picturae mantienen la disposición vertical de la primera; así lo indicaremos oportunamente en el pie de foto. Por último, hemos decidido obviar la numeración de las empresas para evitar posibles confusiones, identificándolas por su lema o mote.

3. El perfil de hombre de letras de Felipe IV queda de manifiesto en la autosemblanza literaria que incluye como epílogo a su traducción de los libros octavo y noveno de la Historia de Italia, de Francesco Guicciardini, en la que confiesa su interés por «leer diversos libros de todas lenguas... que despertasen el gusto de las buenas letras», merced a los cuales «me puse en estado de poder discurrir sobre todo lo universal con gran prontitud». Historia de Italia... por Francisco Guicciardini. Traducida de la italiana en lengua castellana con la vida del autor por D. Felipe IV, Rey de España, tomo I, Viuda de Hernando y Ca, Madrid, 1889, p. Xi. Sobre esta faceta del monarca, véase Fernando Bouza Álvarez: El Libro y el Cetro. La Biblioteca de Felipe IV en la Torre Alta del Alcázar de Madrid, Instituto de Historia del Libro, Salamanca, 2005. El estudio se centra en el Índice de libros confeccionado en 1637, por lo que por una cuestión puramente cronológica no figuran en él las Empresas políticas de Saavedra Fajardo, si bien constatamos la presencia de obras de naturaleza emblemática de autores como Alciato (en la traducción de sus Emblemas de Diego López), Girolamo Ruscelli, Paolo Giovio y Juan de Horozco y Covarrubias.

4. Sagrario López Poza: «Fuentes del programa iconográfico de la portada de Idea de un príncipe político christiano de Saavedra Fajardo (1640 y 1642)», Empresas políticas, n. ${ }^{\circ}$ 6, 2005, pp. 129-142.

5. No pretendemos profundizar en la complejidad histórica de los asuntos tratados, sino alumbrarlos a la luz de la teoría política de Saavedra Fajardo. Para un conocimiento más amplio, nos remitimos a los estudios de Morte ACín, Misticismo y conspiración...; y José MARTínez Millán: «Política y religión en la corte: Felipe IV y sor María de Jesús de Ágreda», en José Martínez Millán, Manuel Rivero Rodríguez y Gijs Versteegen (coords.): La Corte en Europa: Política y Religión (siglos XVI-XVII), vol. III, Polifemo, Madrid, 2012, pp. 1377-1455. 
el Consejo Real en $1644^{6}$ hasta el propio testamento de Felipe IV, ${ }^{7}$ sin dejar de lado otros testimonios como las revelaciones del alma del príncipe Baltasar Carlos a sor María en $1646 .{ }^{8}$

También en las cartas radica una visión providencialista de los acontecimientos, derivada del hecho de que el rey proclama la motivación puramente religiosa de su política y reitera la unión indisoluble entre Dios y la monarquía, que obtendrá el favor divino al sustentarse en la religión; ${ }^{9}$ es más, ante la carencia de medios humanos y económicos, Felipe IV se acoge a «su Divina Majestad que no ha de permitir la pérdida de estos reinos» (2912-1643). ${ }^{10}$ Sor María alienta esta actitud al asegurarle que «no consisten las victorias en numerosos ejércitos, sino en la voluntad del Altísimo» (211-1656). ${ }^{11}$ Las convicciones de ambos coinciden plenamente con la empresa Auspice Deo ${ }^{12}$ (Bajo los auspicios divinos), en la cual Saavedra se sirve de la imagen del venablo de Rómulo lanzado erróneamente contra un jabalí y clavado en el suelo donde floreció [Fig. 2], para mostrar a los príncipes que no son el valor o la prudencia los que sustentan las monarquías, sino la providencia divina; porque «todo depende de aquella eterna Providencia, que eficazmente nos mueve a obrar cuanto conviene para la disposición y efecto de sus divinos secretos», concluye el estadista en una postura que parece implicar cierto determinismo. ${ }^{13}$

6. En octubre de 1644, el Consejo Real aprobó una proclama que había de leerse en todas las iglesias de Castilla, exhortando a los fieles a no dejar de rezar «ya que es por medios espirituales, más que materiales, como se devolverá la integridad a esta monarquía y se la guardará de los enemigos y los rebeldes». RoBERT A. Stradling: Felipe IV y el gobierno de España, 1621-1665, Cátedra, Madrid, 1989, pp. 384 y 428-430; y JOAQUín PÉREz VILlanueva: «Sor María de Ágreda y Felipe IV: un epistolario en su tiempo», en Historia de la Iglesia en España, t. IV. La Iglesia en la España de los siglos XVII y XVIII, Biblioteca de Autores Cristianos, Madrid, 1979, p. 364.

7. «Ruego y encargo a mis sucesores a que gobiernen más las cosas por consideraciones de religión, que no por respeto del estado político; que con esto obligarán a Dios nuestro Señor a que con particularidad los ayude y asista». Testamento de Felipe IV (introducción de Antonio Domínguez Ortiz), Editora Nacional, Madrid, 1982, p. 13

8. Epistolario español, vol. $v$, p. 262.

9. Correspondencia con Felipe IV, p. 44.

10. Son continuos los ejemplos de la visión providencialista del monarca, como puede comprobarse en las cartas de 25-3-1645, 15-5-1645, 22-6-1645, 28-6-1645, 15-2-1646, 29-7-1648, 11-1-1656, 1-2-1656 y 16-7-1657.

11. Acerca de su visión providencialista, véase María Pilar Manero Sorolla: «Sor María de Jesús de Ágreda y el providencialismo político de la Casa de Austria», en Monika Bosse, Barbara PotThast y ANDRÉ STOLL (eds.): La creatividad femenina en el mundo barroco hispánico, vol. I, Reichenberger, Kassel, 1999, pp. 105-125.

12. Este es el mote de la empresa a partir de la edición milanesa de 1642; en la primera edición (Múnich, 1640) era Nascente monarchia florent arma.

13. Diego SaAvedra Fajardo: Empresas políticas (ed. Sagrario López Poza), Cátedra, Madrid, 1999, pp. 929-935. En su Corona Gótica (1658), Saavedra insiste en la misma idea: «ninguna política mayor que obligar a Dios y esperar de su divina providencia y no de las artes humanas, el premio». DiEgo SAAVEDRA FAJARDo: Corona Gótica Castellana y Austríaca (ed. José Luis Villacañas), Tres Fronteras, Murcia, 2008, p. 173. Sobre el providencialismo en el pensamiento de Saavedra, véase Francisco MuriLlo Ferrol: Saavedra Fajardo y la política del Barroco, Centro de Estudios Constitucionales, Madrid, 1989, pp. 94-108. 


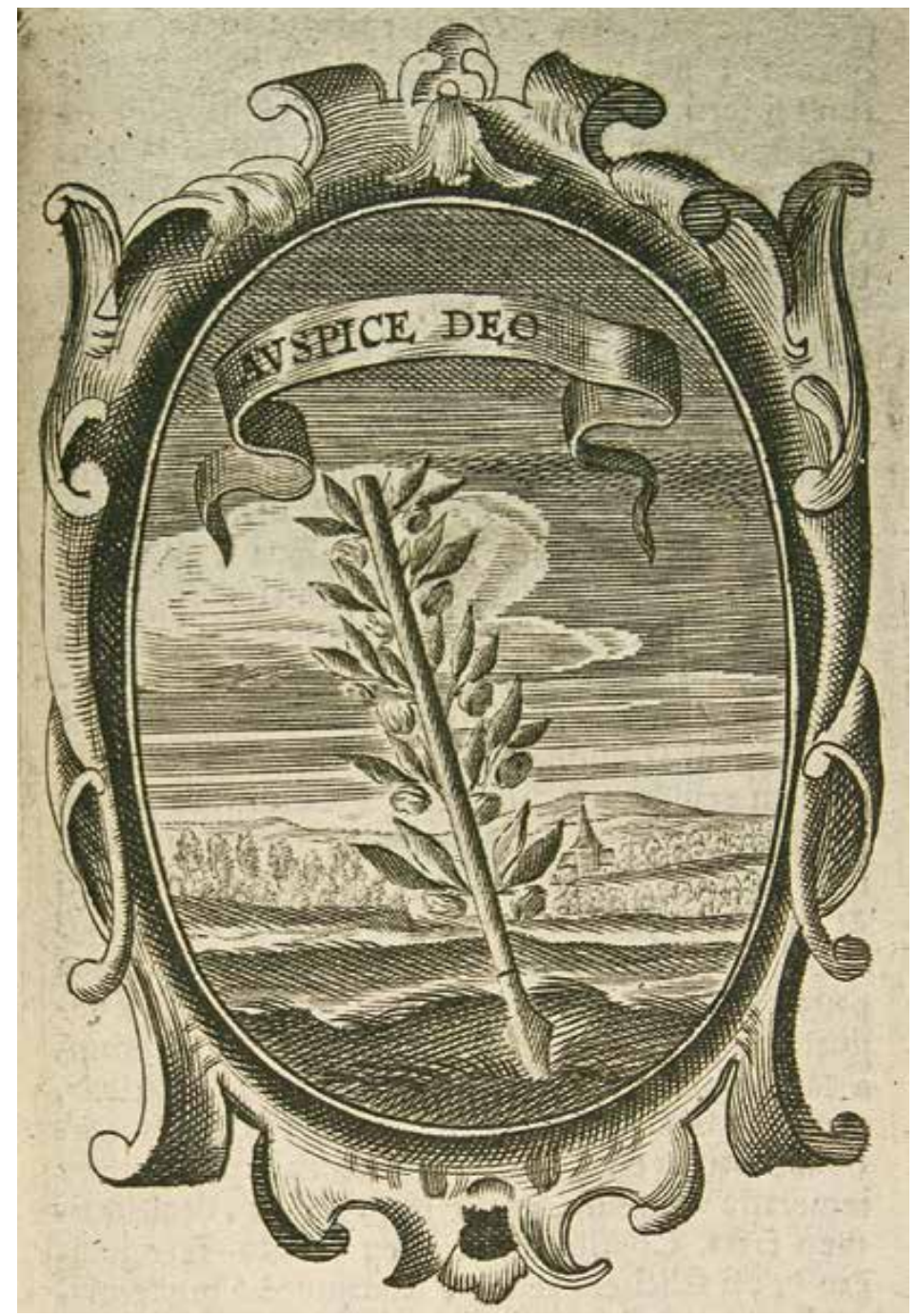

Fig. 2. Auspice Deo (Bajo los auspicios divinos) (1659)

La causa de la monarquía española resulta en consecuencia justa al encaminarse a la defensa de la religión católica, y por tanto cualquier príncipe español que entre en campaña tiene derecho a solicitar el favor del In hoc signo (Bajo este signo), lema de la empresa de Saavedra en la que delante de un campo de batalla, una mano sujeta el lábaro de Constantino [Fig. 3]; pues al igual que el emperador insertó en su enseña la cruz y el monograma de 
Cristo, y obtuvo la victoria, los príncipes cristianos deben tener confianza en la divina providencia al enarbolar contra sus enemigos el estandarte de la religión. Explícito se muestra en este sentido el propio Felipe IV al afirmar que «nuestra defensa ha de venir de la poderosa mano de Nuestro Señor» (15-2-1646); y al igual que la mano sustenta el estandarte en la composición saavedriana, también la plaza de Lérida fue «conquistada y defendida por su brazo poderoso»(29-5-1647); el socorro de Gerona fue «suceso solo encaminado de su poderosa mano» (13-10-1653); y en la empresa de Olivenza obró «únicamente la mano de nuestro Señor» (25-6-1657). Evidentemente, sor María coincide con este planteamiento, aconsejando al monarca que abrace la cruz de Cristo «y con este estandarte triunfe de los enemigos visibles e invisibles, domésticos y extraños» (28-8-1648).

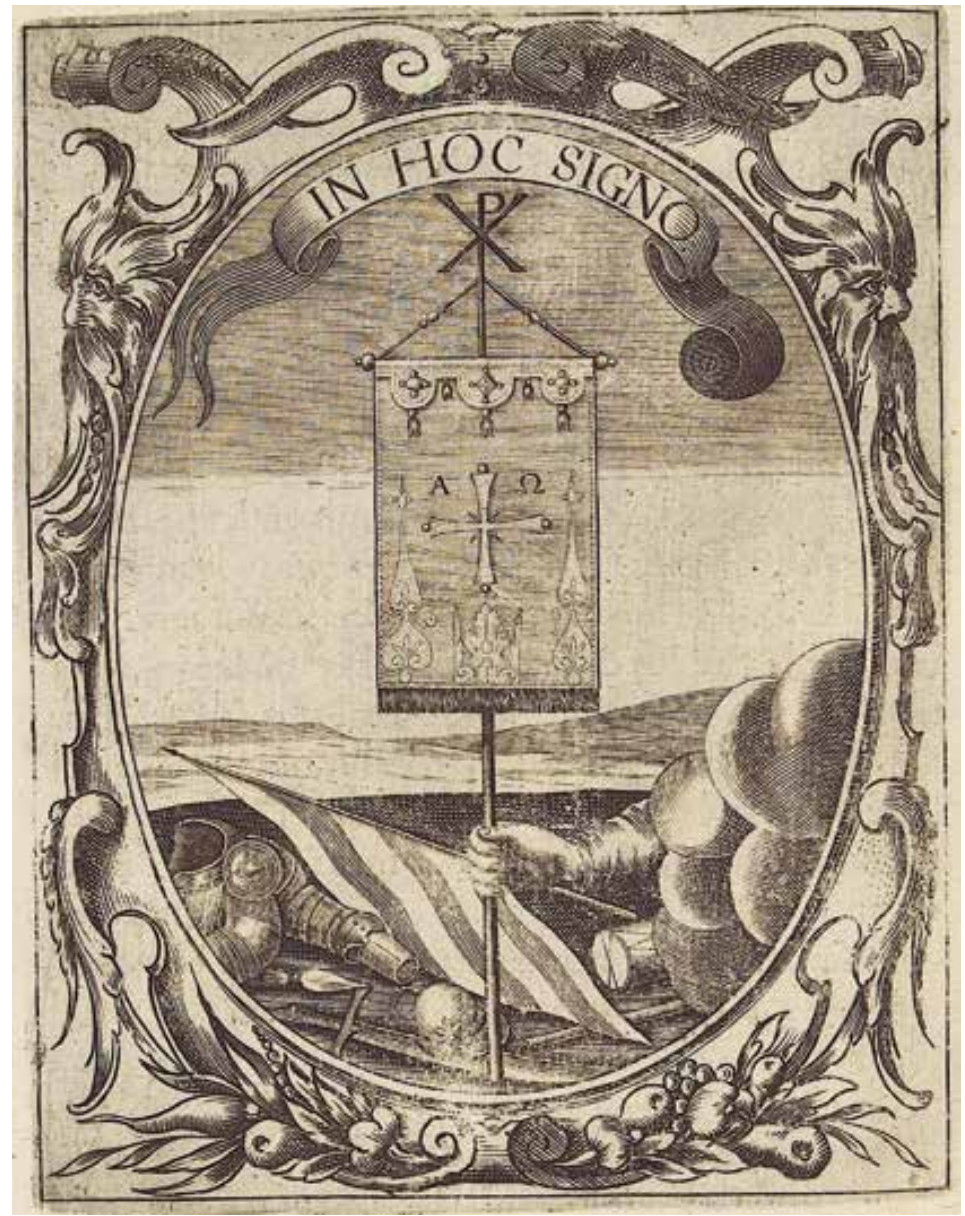

Fig. 3. In hoc signo (Bajo este signo) (1640) 
Pese a todo, hay veces en que la suerte resulta contraria; en esos casos, debe pensarse que la providencia así lo dispone, lo que lleva en última instancia al acatamiento de la voluntad divina, aunque no siempre se entiendan los designios de Dios. Tal comportamiento resulta una constante en Felipe IV, quien asevera que, una vez solicitada la ayuda de Nuestro Señor, «en todo estaré conforme con su santa voluntad, creyendo firmemente que lo que dispone su Providencia es lo mejor» (8-6-1645). ${ }^{14}$ Afloran continuamente en las cartas preocupaciones por tantos contratiempos personales y políticos que se acumulan en estos años, ante los que el monarca reacciona desde el providencialismo que le conduce a aceptar la voluntad divina tanto en la prosperidad como en la adversidad. Así queda de manifiesto con motivo de las muertes de su esposa Isabel de Borbón (15-11-1644), de su sobrino el Rey de Romanos (9-9-1654), o de su hijo Felipe Próspero (8-11-1661); y, en el terreno político-militar, ante la pérdida de Rosas (6-6-1645) y de Flix (4-9-1645), la difícil situación en Flandes (31-8-1646), o el fracaso en el intento de la toma de Arras, por cuanto «es menester bajar la cabeza y conformarnos con la voluntad de Dios» (9-9-1654). La propia sor María reconforta en numerosas ocasiones al monarca, recordándole que «el mayor alivio ante los trabajos es la conformidad» (4-10-1658). En esta ocasión, la actitud de Felipe IV queda reflejada en la empresa Volentes trahimur (Somos guiados voluntariamente), en la que una mano que surge de una nube sostiene una piedra-imán de la que pende, adherido por su punta, un puñal [Fig. 4]; pues así como el imán atrae el hierro venciendo la ley de la gravedad, también el príncipe debe dejarse conducir por la voluntad divina. ${ }^{15}$

Indudablemente, Felipe IV es consciente de que el acatamiento de esta última con grandeza de ánimo conviene a su dignidad y reputación como rey; la constancia de ánimo es virtud fundamental del monarca, que no debe mostrar excesiva perturbación en la adversidad ni exaltarse en extremo ante los éxitos. Así lo expresa Saavedra en sus empresas Existimatione nixa (Apoyada en la reputación) y Siempre el mismo, aseverando que el príncipe debe mantener la fortaleza tanto en la fortuna próspera como en la adversa en beneficio de su pueblo, que mira hacia él como un espejo de virtudes; tal idea entronca con algunas de las virtudes (constantia, patientia, firmitas) más estimadas por Lipsio y sus seguidores neoestoicos, cuya doctrina resulta perceptible en Saavedra. ${ }^{16} \mathrm{Y}$ queda de manifiesto en numerosas cartas filipinas, principalmente en la que escribe en Zaragoza para comunicar a sor María la muerte de su hijo Baltasar Carlos, que se convierte en ejemplo de entereza al aceptar que «justo es Dios, y así no puede errar en nada, y aunque a nosotros

14. En la misma línea se inscriben manifestaciones recogidas en sus cartas de 8-8-1645, 16-8-1645, 4-91645, 20-4-1654 y 10-10-1656.

15. SaAVedra Fajardo, Empresas políticas, pp. 936-945.

16. Ibidem, pp. 435-443 y 450-460. Véase también Sagrario López Poza: «Virtudes neoestoicas en las Empresas políticas de Saavedra Fajardo. La influencia de Justo Lipsio», Empresas políticas, n. ${ }^{\circ}$ 4, 2004, 139-150; idem: «La Política de Lipsio y las Empresas políticas de Saavedra Fajardo», Res publica, n. 19, 2008, pp. 209-234. 


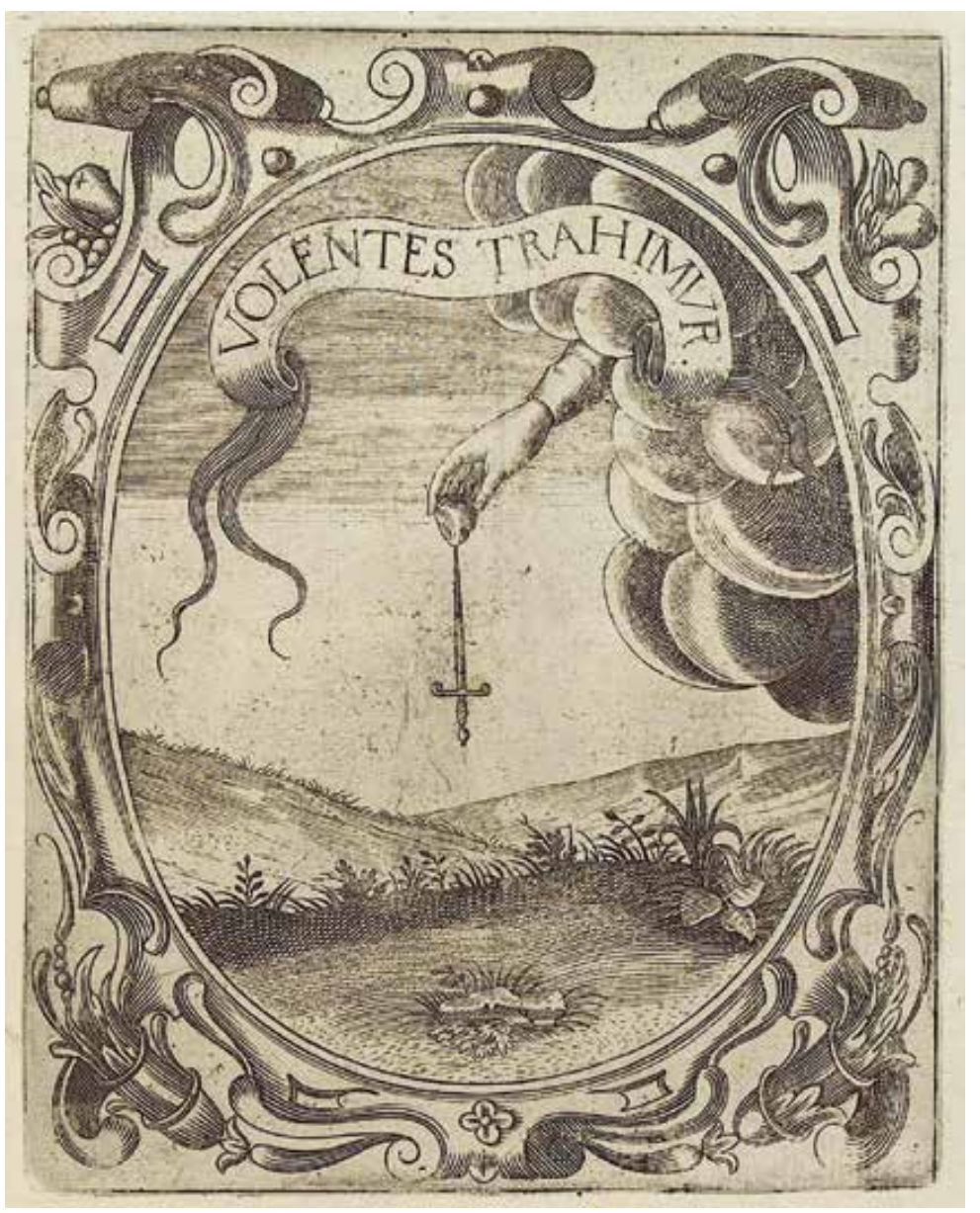

Fig. 4. Volentes trahimur (Somos guiados voluntariamente) (1640)

no nos es permitido alcanzar sus secretos, debemos conformarnos con su santa voluntad y tener por infalible que lo que obra su Providencia es lo mejor» (10-10-1646). La cristiana conformidad con la voluntad divina se sobrepone al dolor, hasta el punto de que el ánimo con que Felipe IV acogió el golpe más duro que la providencia le reservaba conmovió a toda la corte. ${ }^{17}$ 


\section{EL MONARCA, PRÍNCIPE POLÍTICO-CRISTIANO}

Al frente de la nave de la monarquía se encuentra Felipe IV, que como experto piloto debe encargarse de conducirla a buen puerto. El símil marítimo es empleado en numerosas ocasiones por el monarca para referirse a las dificultades por las que atraviesa su reino, confiando siempre en la intervención divina que permitirá que «de la borrasca que padecemos lleguemos a la quietud y sosiego del puerto» (9-6-1649). ${ }^{18}$

La idea del temporal, tormenta o borrasca que azota a la nave de la monarquía resulta constante en las epístolas filipinas; ${ }^{19}$ y tampoco es ajena a sor María, quien, pese a lamentarse por «las olas turbulentas que combaten a esta Monarquía» (8-3-1647), tiene la firme convicción de que «la navecilla de España no ha de naufragar jamás», rogando al Señor que permita alcanzar al monarca «el puerto seguro de la salvación» (10-8-1645). También Saavedra, mediante la imagen de la nave con vientos contrarios de proa, afirma en su empresa In contraria ducet (Gobierna aun en condiciones desfavorables) que, al igual que en medio de la borrasca el piloto conduce el navío en la dirección que conviene, el príncipe gobernará la nave del Estado solventando las dificultades con prudencia y valor ${ }^{20}$ [Fig. 5].

En el gobierno del Estado, la dedicación y constancia en el trabajo se convierten en una de las principales cualidades del monarca. Felipe IV fue un monarca mucho más profesional y responsable de lo que se supone, que transmite la imagen del «rey en su despacho». ${ }^{21}$ Se repiten a lo largo de sus cartas las alusiones a su infatigable trabajo del que depende tanto su propia salvación como la de sus reinos, asegurando a sor María que «no rehúso trabajo alguno, pues estoy continuamente sentado en la silla con los papeles y la pluma en la mano» (30-1-1647); y años más tarde confiesa que «en el trabajo de los negocios dejo de muy mala gana para mañana lo que puedo hacer hoy» (21-9-1661). ${ }^{22}$ La actitud filipina se encuentra reflejada en varias empresas de Saavedra quien, siguiendo una vez más la corriente neoestoica, insta a la acción del príncipe, pues un gobernante pusilánime constituye un peligro para el reino. ${ }^{23}$ De esta manera, la empresa Fulcitur experientiis (Sustentada en las experiencias), pone de manifiesto la necesidad de actuar, idea que se reafirma en Ferendum et sperandum (Sufriendo y confiando), que insiste en el ánimo

18. También lo vemos en el epílogo de la Historia de Italia, donde se muestra preocupado por «gobernar con acierto el timón de esta nave de la Monarquía, tan dificultosa de ser bien gobernada». Historia de Italia, p. XII.

19. Véanse las cartas de 11-6-1653, 17-12-1653, 22-7-1654, 9-9-1654, 9-6-1655 y 11-1-1656.

20. Los motivos marinos que aparecen en las empresas In contraria ducet (Gobierna aun en condiciones desfavorables) y Minimum eligendum ([Del daño] elegir el menor), proporcionan a Saavedra materia adecuada para expresar algunas de las habilidades del piloto de la nave del estado, como habían servido a Lipsio, que emplea numerosas metáforas marinas. SAAVEdRa FaJARdo, Empresas políticas, pp. 84 y 471-484.

21. Stradling, Felipe IV y el gobierno de España, p. 392.

22. El desvelo en el trabajo figura en las cartas de 15-5-1645, 17-6-1646, 14-11-1646, 3-4-1647 y 1-5-1647.

23. Alfredo Montoya Melgar, «Trabajo, ocio y oficios en las Empresas políticas de Saavedra Fajardo», Murgetana, n. ${ }^{\circ} 76,1988$, pp. 5-45. 


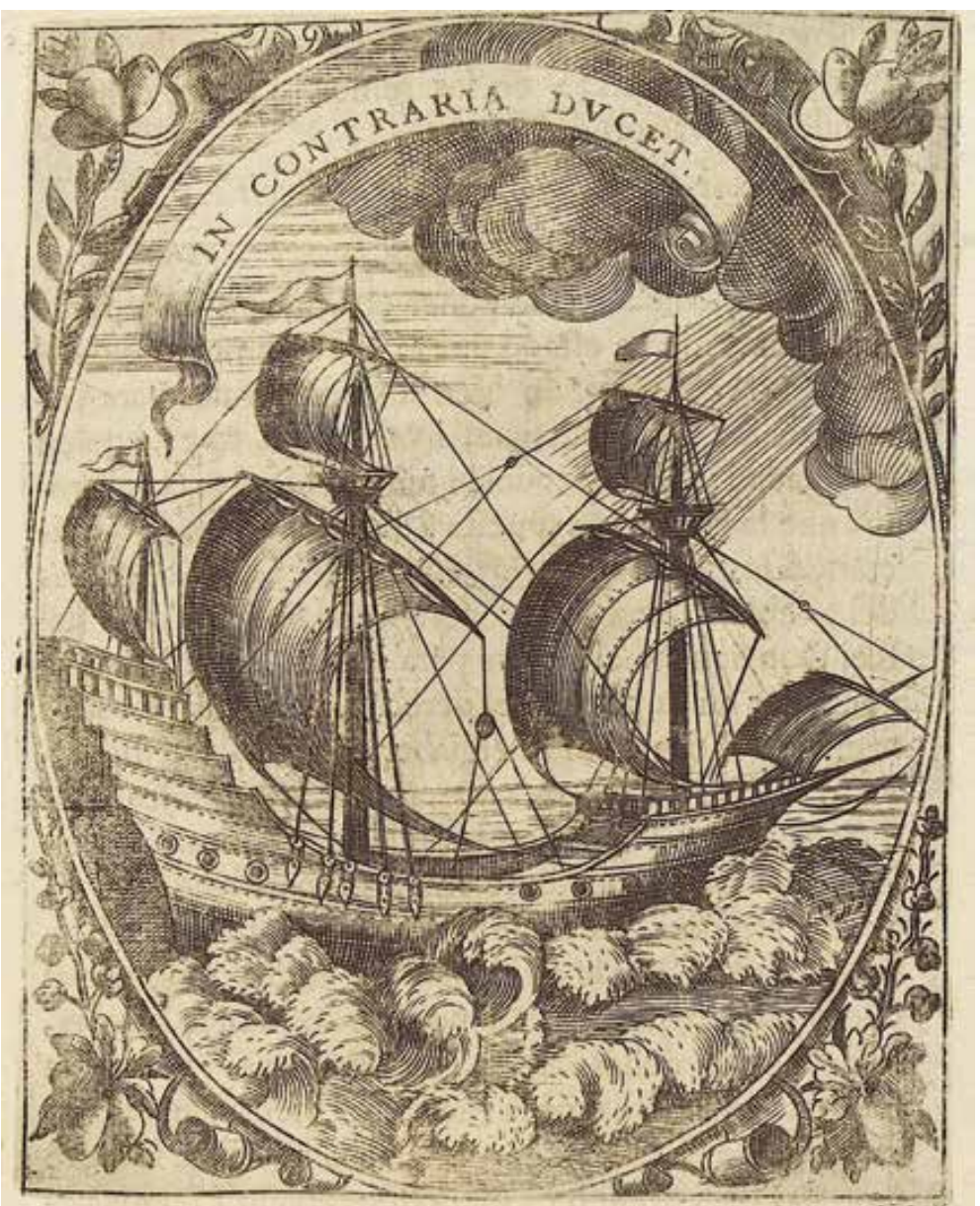

Fig. 5. In contraria ducet (Gobierna aun en condiciones desfavorables) (1640)

constante del príncipe en el trabajo, apoyándose para ello en la sentencia del Eclesiastés 11, 4: «El que espera el viento adecuado no sembrará, el que no hace más que mirar a las nubes no segará». Pero sin duda, la empresa que desarrolla con mayor claridad este concepto es Labor omnia vincit (El trabajo todo lo vence), en cuya pictura aparece un ariete golpeando una muralla en la que ha abierto una brecha [Fig. 6]; al igual que el ariete logra derribar un muro con la insistencia de los golpes, así también el príncipe vencerá cualquier obstáculo mediante la constancia en el trabajo. ${ }^{24}$ 


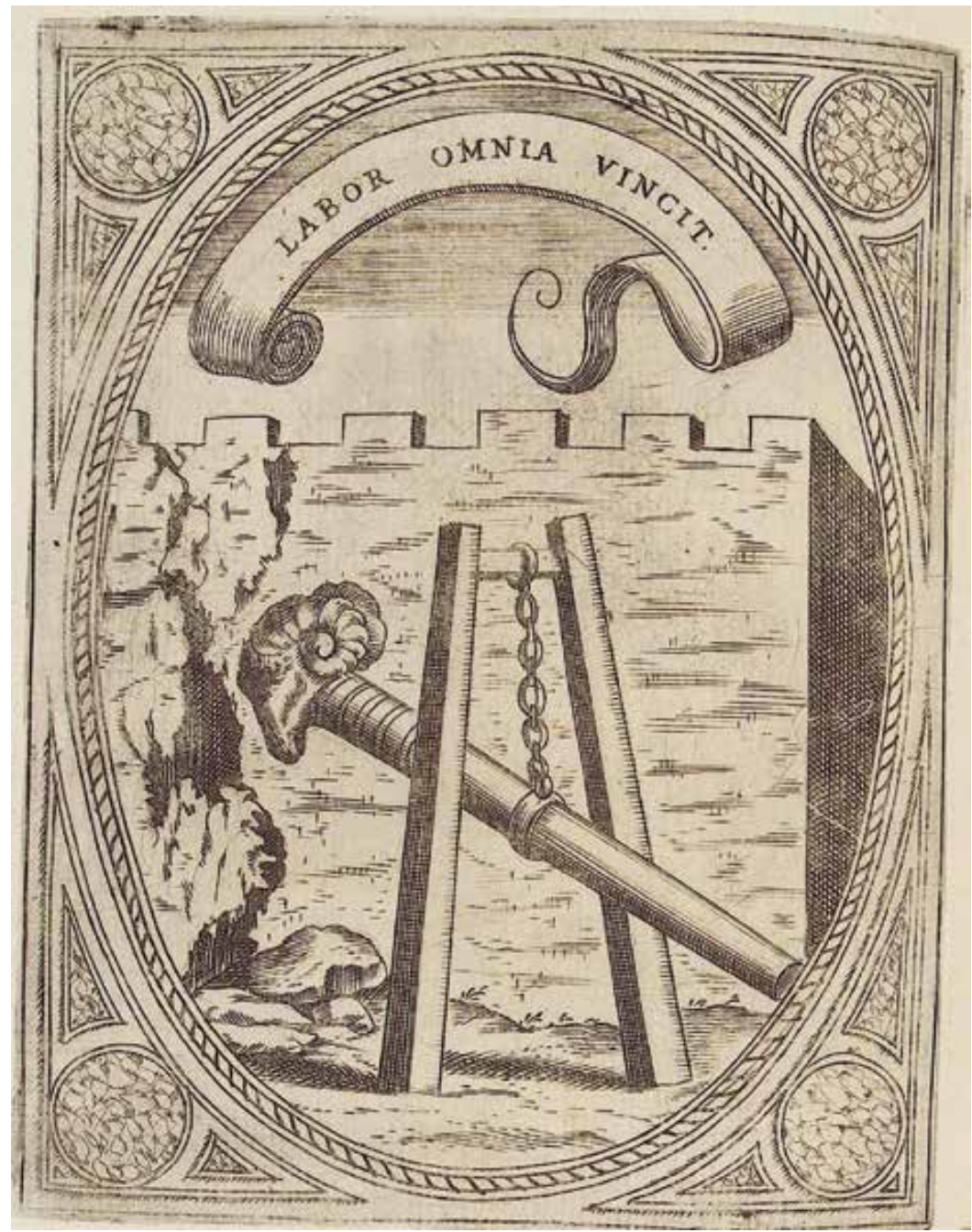

Fig. 6. Labor omnia vincit (El trabajo todo lo vence) (1640)

Felipe IV asume por tanto la responsabilidad plena que tiene por derecho y por deber desde su nacimiento; pero ¿fue realmente un monarca decidido y con autoridad a la hora de tomar decisiones? No todo el mundo parece verlo así, pues hay quien lo acusaba de poseer un carácter pusilánime, entre ellos el embajador veneciano Pietro Bassadona, a cuyo juicio el rey parecía limitado a ejercer un arbitraje impersonal en el gobierno de la monarquía; y se servía del ejemplo del reloj para criticar la falta de decisión del monarca, movido 
tan solo por las ruedas de sus ministros. ${ }^{25}$ Del mismo parecer -aunque con matices - eran el marqués de Osera («El rey deja correr las cosas») y la condesa de Osorno, a cuyo entender el rey «hacía lo que le parecía», evidenciando una notable falta de resolución. ${ }^{26}$ También sor María es consciente de la debilidad filipina en su labor de gobierno, de manera que le alienta a actuar con presteza, pues «lo que se ha de hacer tarde o temprano mejor es prevenirlo con tiempo, que exponerlo al peligro interponiendo tantas dilaciones» (25-7-1648). ${ }^{27}$ La firmeza que solicita la religiosa se encuentra en relación con la empresa Resolver $i$ executar, en la que las ruedas del carro falcado de cuya velocidad depende la rapidez de las cuchillas, recuerdan al príncipe la necesidad de que vayan unidas la resolución tomada y su ejecución, sin un retraso que restaría eficacia [Fig. 7]. No ha de haber dilación entre decisión y ejecución, de manera que ambas tengan entre sí tal correspondencia «que parezca es un mismo movimiento el que las gobierna», concluye Saavedra.

Entre los trabajos del monarca se encuentran los viajes por sus dominios y el conocimiento de sus súbditos; tras la desaparición de Olivares, Felipe IV se encuentra por primera vez solo ante las responsabilidades del gobierno, y las nuevas circunstancias conducen a un comportamiento inhabitual que le obliga a abandonar la corte y recuperar la tradición del «monarca viajero» propia de la época de los Reyes Católicos y de Carlos V. Entre 1643 y 1646, los viajes son constantes, situación que asume con naturalidad como parte de sus obligaciones, aunque ello suponga dejar la comodidad de la corte y distanciarse de su familia, pues «primero es el cuidado de mis reinos que el gusto de asistir con tales prendas», refiere a sor María (29-12-1643). El rey viaja tanto para acercarse a los problemas de sus estados como para que sus súbditos le sientan próximo, mostrándose respetuoso con sus privilegios y costumbres, pues la situación de la monarquía aconsejaba una delicadeza exquisita en el trato con los diversos reinos. Pero la mayoría de sus viajes tienen por objeto ponerse al frente de su ejército en la guerra que se libra contra Francia en Cataluña; consciente de la importancia de su presencia, no duda en asumir los riesgos que entrañan los viajes para insuflar ánimo a las tropas. Así lo hace saber a la monja: «No he reparado en dejar la comodidad de mi casa solo por acudir

25. Epistolario español, vol. IV. Cartas de sor María de Jesús de Ágreda y de Felipe IV, LIII-LIV. A este respecto, Sánchez de Toca opina que, si arriesgado era que el rey depositara la labor de gobierno en un valido, «era no menos sujeto a grandes desaciertos y torpezas de gobierno el intentar que una voluntad sin firmeza como la de Felipe IV fuese la única fuerza motora de toda nuestra máquina del Estado», dada la incapacidad personal del monarca para gobernar por sí. JoAquín SÁNCHEZ DE ToCa: Felipe IV y Sor María de Ágreda, Minerva, Barcelona, 1930, p. 179. Por su parte, Marañón denuncia la «voluntad paralítica» y la «parálisis de la decisión y de la iniciativa» del monarca. Gregorio MARAÑón: El conde-duque de Olivares, Espasa-Calpe, Madrid, 1952, pp. 232-234.

26. Escribir la Corte de Felipe IV: El Diario del Marqués de Osera, 1657-1659 (ed. Santiago Martínez Hernández), Centro de Estudios Europa Hispánica y Ediciones Doce Calles, Madrid, 2013, pp. 72-73.

27. Reflexiones de esta naturaleza encontramos en las cartas de 28-2-1646, 14-7-1646, 15-2-1647 y 9-8-1658. 


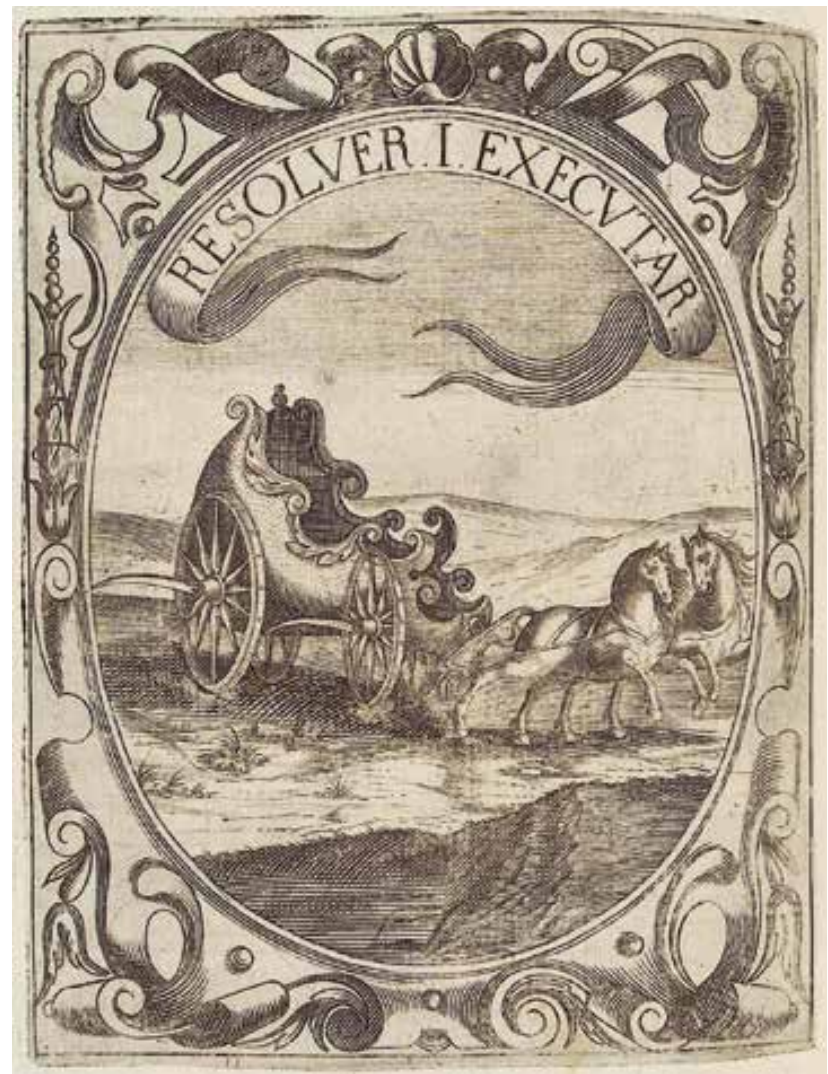

Fig. 7. Resolver i executar (1640)

personalmente a la defensa destos reinos» (25-3-1645). ${ }^{28}$ La propia religiosa alienta la decisión del monarca al afirmar, a propósito del socorro de Lérida: «Veo muchas conveniencias en que asistiera la persona real de Vuestra Majestad en su defensa, para que el ejército se juntase» (21-7-1647).

Las salidas de Felipe IV de la corte se convierten en toda una cuestión de Estado al ser contrarias a la opinión de algunos de sus consejeros, que le recordaban que «Dios puso el árbol de la vida en medio de su paraíso, y el sol en medio del cielo»; pero tampoco faltaron al monarca estímulos literarios para acercarse al campo de batalla, entre ellos los de Gracián y Quevedo. ${ }^{29}$ En la

28. En parecidos términos se expresa en diversas cartas de esta época, como las de 9-3-1644 y 18-101645. Incluso en una fecha ya tardía como 1658 el monarca está dispuesto a acudir en persona al socorro de Badajoz «si la necesidad lo pidiere», pues tan importante resulta la conservación de la plaza (30-7-1658).

29. El primero, en su obra El político Don Fernando el Católico, destacaba las ventajas de que un rey se pusiera al frente del ejército, afirmando que «el ver sus soldados un rey es premiarlos, y su presencia 


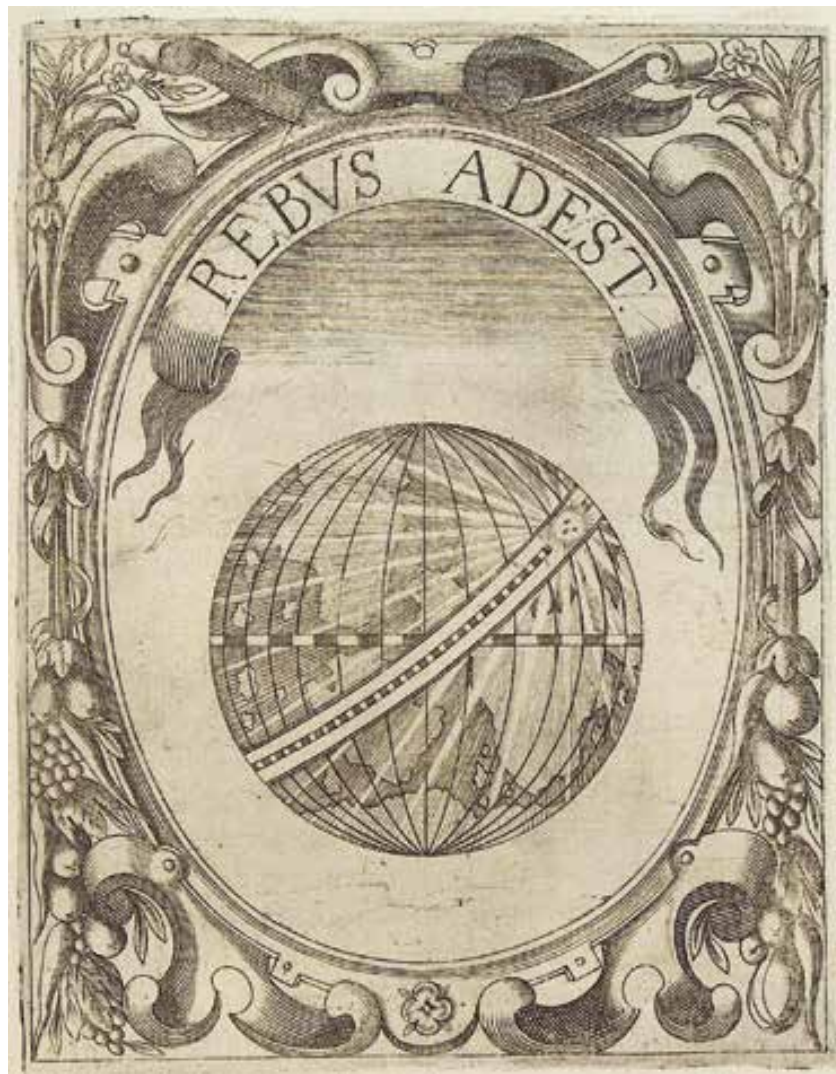

Fig. 8. Rebus adest (Está presente en todo) (1640)

misma línea se manifiesta Saavedra, quien alude con frecuencia a la obligación del príncipe de viajar y conocer sus estados. Así, en la empresa Más que en la tierra nocivo, considera la importancia de que tenga gran conocimiento de sus vasallos para acertar en sus decisiones de gobierno, idea que desarrolla más por extenso en Regit et corrigit (Rige y corrige), que insiste en la idea del príncipe prudente que conoce y gobierna sus estados sin innovar las costumbres. Pero la empresa que verdaderamente ejemplifica el comportamiento de Felipe IV es Rebus adest (Está presente en todo), cuya pictura muestra una esfera terrestre

vale por otro ejército». En cuanto a Quevedo, en la Política de Dios defiende la presencia del rey en los momentos de peligro, pues «rey que pelea y trabaja delante de los suyos, oblígalos a ser valientes». También el político y escritor portugués Francisco Manuel de Melo recomienda que «salga el rey de su corte, acuda a los que le han menester, llegue a Aragón, pise Cataluña, muéstrese a sus vasallos, satisfágalos, mírelos y consuélelos». María Soledad ArRedondo: «Armas de papel. Quevedo y sus contemporáneos ante la guerra de Cataluña», La Perinola, n. ${ }^{\circ}$ 2, 1998, pp. 117-151. 
con los meridianos y paralelos y una franja oblicua de la elíptica por la que discurre un sol faciado que desprende rayos, para dar a entender que, al igual que el sol camina infatigable de un trópico a otro, así los príncipes deben recorrer sus estados para atender personalmente los asuntos tanto en la paz como en la guerra [Fig. 8]. Incluso la expresión «dar calor» que leemos en las cartas es empleada por el murciano, para quien la presencia del monarca resulta determinante en caso de guerra, pues guía a los vasallos y da ánimo a los soldados; no obstante, debe ponderar las salidas, considerando tan solo aquellos conflictos que tienen lugar dentro de su mismo Estado o allá donde suponen una amenaza para él, pero sin alejarse tanto de su reino como para ponerlo en peligro. Así actuó precisamente el rey en la guerra con Francia en Cataluña, en una situación de extrema gravedad que amenazaba las fronteras del reino.

En sus viajes por los reinos y escenarios de la guerra, Felipe IV decide que su sucesor, el malogrado Baltasar Carlos, lo acompañe desde muy joven, por cuanto considera esencial que el futuro rey adquiera experiencia de gobierno desde su más tierna edad: «He querido que empiece ya el príncipe a ir aprendiendo lo que le ha de tocar después de mis días», escribe a sor María en carta fechada en Zaragoza el 25-3-1646. Esta iniciativa puede ponerse en contacto con la empresa Robur et decus (Fortaleza y belleza), que muestra una rama de coral que emerge del mar y se endurece al contacto con el viento [Fig. 9] para indicar que hay que fomentar en el joven príncipe el interés por el arte de la guerra desde pequeño, tal y como hicieron entre otros Fernando el Católico, criado entre soldados en el campo de batalla, y Carlos V.

Pero no todo puede ser trabajo y viajes en el príncipe político-cristiano, que también merece gozar de jornadas de descanso; así lo reconoce el propio monarca al comentar a sor María que «para trabajar más es menester tomar de cuando en cuando algún alivio en el campo» (6-11-1647)». De esta manera, las estancias más o menos breves en los Sitios Reales se repiten de forma periódica; ${ }^{30}$ la tranquilidad del campo, el disfrute de la caza, o el retiro espiritual en San Lorenzo, resultan sumamente gratos a Felipe IV, quien sin embargo no abandona por completo sus deberes al frente de la monarquía, por lo que podemos hablar con más propiedad de un «descanso activo». ${ }^{31} \mathrm{Y}$ así, el rey acude a El Escorial, «donde hay muy buenos campos y caza, con que me divierto algo sin faltar a los despachos» (2-11-1648); disfruta en Aranjuez, si bien «detúveme poco allí, por volver a asistir más cerca a los negocios» (10-51651); y acompaña durante unos días a la familia real en el Pardo, que «como

30. Sobre la importancia que desde el siglo XVII adquieren los Reales Sitios en el contexto de la formación y evolución de la organización política de la monarquía hispana, véase José ElOY HorTAL MuÑoz. «La integración de los sitios reales en el sistema de corte durante el reinado de Felipe IV», Libros de la Corte.es, n. ${ }^{\circ} 8,2014$, pp. $27-47$.

31. Sobre el concepto de descanso regio en el ámbito político de la Edad Moderna, véase José JAVIER Azanza López: «¿Descansa Su Majestad? Aproximación a una teoría político-emblemática hispana del descanso regio», Potestas. Revista del Grupo Europeo de Investigación histórica. Religión, poder y monarquía, n. ${ }^{\circ}$ 4, 2011, pp. 107-146. 


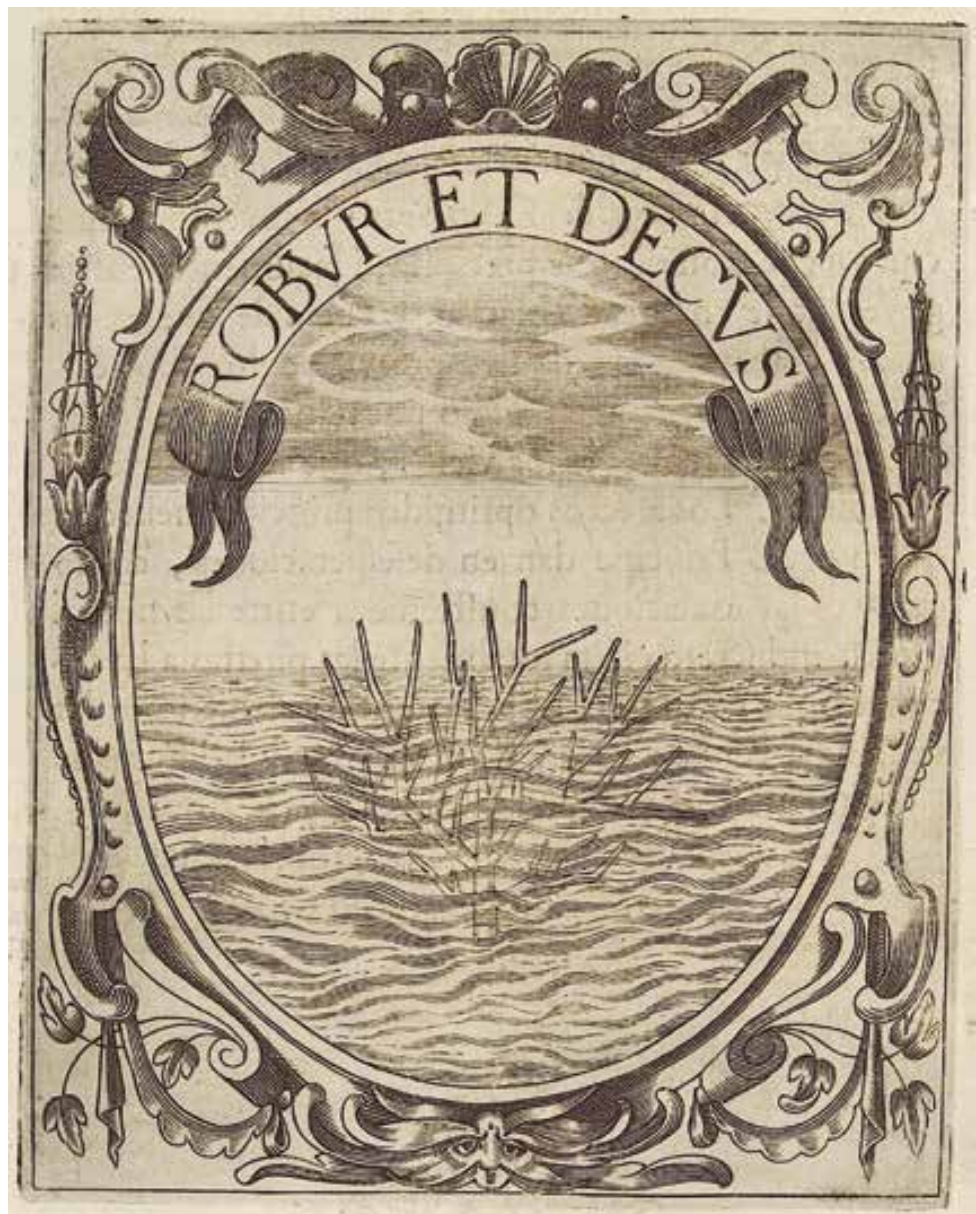

Fig. 9. Robur et decus (Fortaleza y belleza) (1640)

no está a más de dos leguas de aquí, se puede gozar del campo sin faltar a los negocios» (6-1-1654). ${ }^{32}$ Tal actitud hay que ponerla en relación con la empresa Vires alit (Alimenta su fuerza), en la que una mano se posa sobre el caño de una fuente para impedir que surja, pero el agua, con más fuerza, se escapa entre los dedos [Fig. 10]; el descanso, que reaviva las fuerzas, es necesario en todo trabajo, como lo muestra el agua que, interrumpido su curso, sale con

32. Referencias similares aparecen continuamente en la correspondencia de Felipe IV a sor María, llegando a intensificarse en los últimos años; sirvan como ejemplo, además de las mencionadas, las cartas de 28-4-1648, 11-2-1650, 4-1-1651, 15-1-1652, 2-10-1652, 20-4-1654, 17-10-1655, 30-12-1656, 22-5-1657, 20-11-1657, 6-11-1658, 21-4-1659, 18-10-1659, 13-10-1660 у 22-1-1661. 
más vitalidad. Matiza, no obstante, que el reposo del príncipe ha de ser sobre los mismos negocios a los que ni siquiera en estos momentos debe perder de vista, tal y como hacía Fernando el Católico, que «cuando salía de caza, tenía los oídos atentos a los despachos que le leía un secretario, y los ojos al vuelo de las garzas». Siguiendo los consejos de Saavedra, el paralelismo entre Felipe IV y sus antepasados resulta evidente.

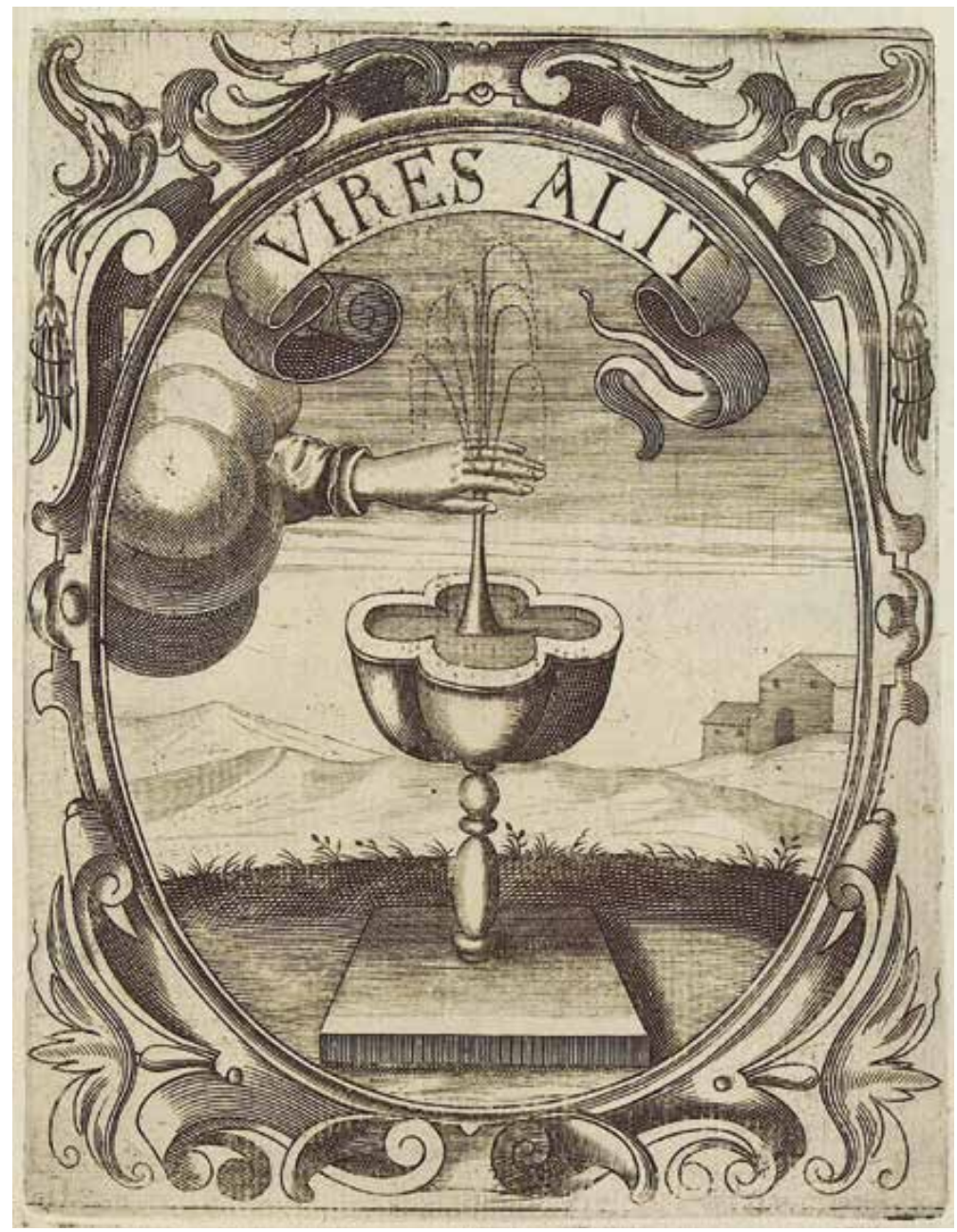

Fig. 10. Vires alit (Alimenta su fuerza) (1640) 


\section{EL ARTE DE GOBERNAR VIRTUOSAMENTE A SUS VASALLOS}

En el gobierno de sus estados, el príncipe político-cristiano debe valerse de sus virtudes, que lo convierten en espejo y modelo de comportamiento para todos sus vasallos.

La prudencia es la virtud política por excelencia del príncipe, concretándose en la mayoría de las ocasiones en el disimulo, al ocultar con astucia acciones y pensamientos. ${ }^{33}$ La idea del disimulo aparece continuamente en la correspondencia entre Felipe IV y sor María, por cuanto se trata de un concepto plenamente asimilado por el monarca en sus labores de gobierno. Así queda de manifiesto al referirse a la relación con sus ministros, en la que «me hallo obligado a disimular» (4-9-1645); en la difícil negociación con las Cortes de Aragón que se muestran renuentes a conceder los socorros para la guerra, al insistir una y otra vez en que «es menester disimular» (27-7-1646); o a propósito de las insurrecciones surgidas en Sicilia y Nápoles, al reconocer que «en estos tiempos de borrasca es menester valerse de la disimulación y tolerancia más que de la fuerza» (21-8-1647).

La actitud del monarca coincide plenamente con Saavedra, a cuyo juicio todas las acciones de gobierno deben estar asistidas por la prudencia que aconseja la razón de Estado; en este contexto, el disimulo se convierte en la gran virtud del monarca, y a ella dedica varias empresas. La más significativa es Ut sciat regnare (Para que sepa reinar), lema inspirado en la sentencia que el rey Luis XI de Francia consideraba única en la instrucción de su hijo Carlos VIII; ${ }^{34}$ muestra en su pictura un solio real de cuyo dosel pende la piel del león de Nemea con la cabeza coronada de serpientes, dando a entender que, para saber reinar, conviene al príncipe cubrir la fuerza y el valor con la prudencia y el disimulo, acomodándose a las circunstancias y sin sobrepasar los límites del engaño ${ }^{35}$ [Fig. 11].

33. Acerca del disimulo como actitud propugnada por los textos emblemáticos, véase SAgRARIO López PozA: «El disimulo como virtud política en los tratados emblemáticos españoles de educación de príncipes», Estudios sobre Literatura Emblemática Española, Sociedad de Cultura Valle Inclán, La Coruña, 2000, pp. 221-233; y Miguel Grande YÁNEZ: «La relevancia de la disimulación en Saavedra Fajardo», Res publica, n. ${ }^{\circ} 19,2008$, pp. 189-200. En un contexto más amplio que reflexiona en torno al secreto y el silencio, la disimulación y el engaño, en la teoría política de la Edad Moderna, con alusiones a Saavedra y a la correspondencia entre Felipe IV y sor María, David SeIz Rodrigo: La disimulación honesta. Los Gastos Secretos en el reinado de Felipe IV entre la razón de estado y la merced cortesana, Endymion, Madrid, 2010, pp. 45-89.

34. Qui nescit disimulare, nescit regnare (Quien no sabe disimular, no sabe reinar).

35. Una enseñanza similar contienen las empresas Nec a quo, nec ad quem (Ni de quién ni para quién), en la que la serpiente se convierte en símbolo de la prudencia del príncipe por su habilidad para moverse sin que nadie adivine su curso; y Non maiestate securus (No por la majestad seguro), en la que al igual que el león duerme con los ojos entreabiertos, así también el príncipe ha de disimular y hacer creer a todos que está en vigilancia permanente. Y en las empresas A Deo (De Dios), Praesidia maiestatis (Defensas de la Majestad), Ne te quaesiveris extra (No te busques fuera), y Lumine solis (Por la luz del sol), se trata de lo conveniente que resulta al príncipe el disimulo, considerando el diplomático la necesidad de sopesar sus acciones y de no dejarse llevar por la venganza. 


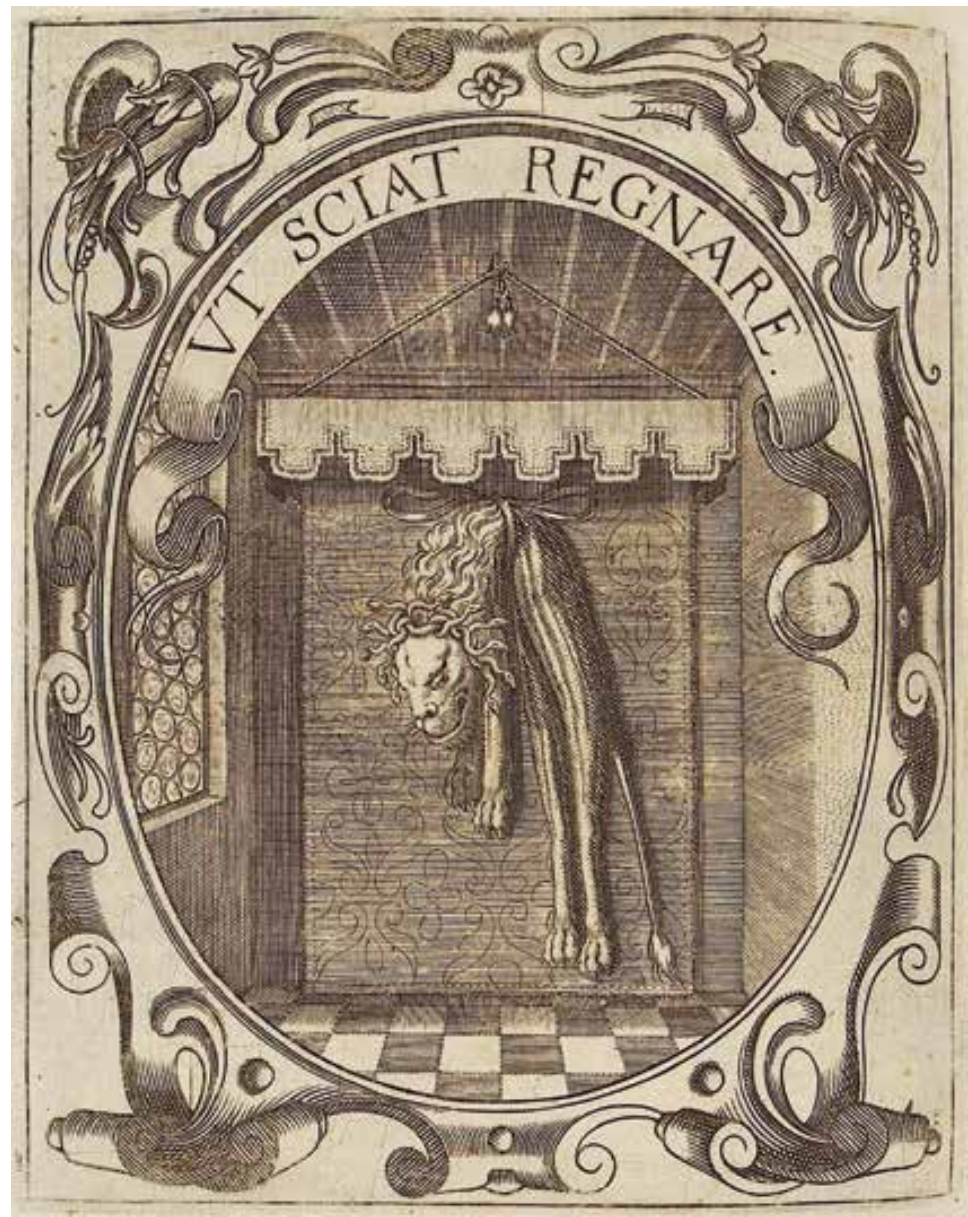

Fig. 11. Ut sciat regnare (Para que sepa reinar) (1640)

No todos los allegados al monarca le aconsejaron adoptar siempre esta postura; y así, el duque de Alcalá denunciaba desde su virreinato de Nápoles en 1629 que «ha llegado la hora de quitarse la máscara del disimulo y vérselas de una vez para siempre con Francia». ${ }^{36}$ Por el contrario, sor María alaba la prudencia en el gobernante, «virtud que, entre las cardinales, es la mayor y más principal», de manera que «los reyes y príncipes la necesitan mucho»; el monarca prudente será justo, esforzado y piadoso, y «se enmienda de lo

36. Carta del duque de Alcalá a Olivares, 27-4-1629. Stradling, Felipe IV y el gobierno de España, p. 151 


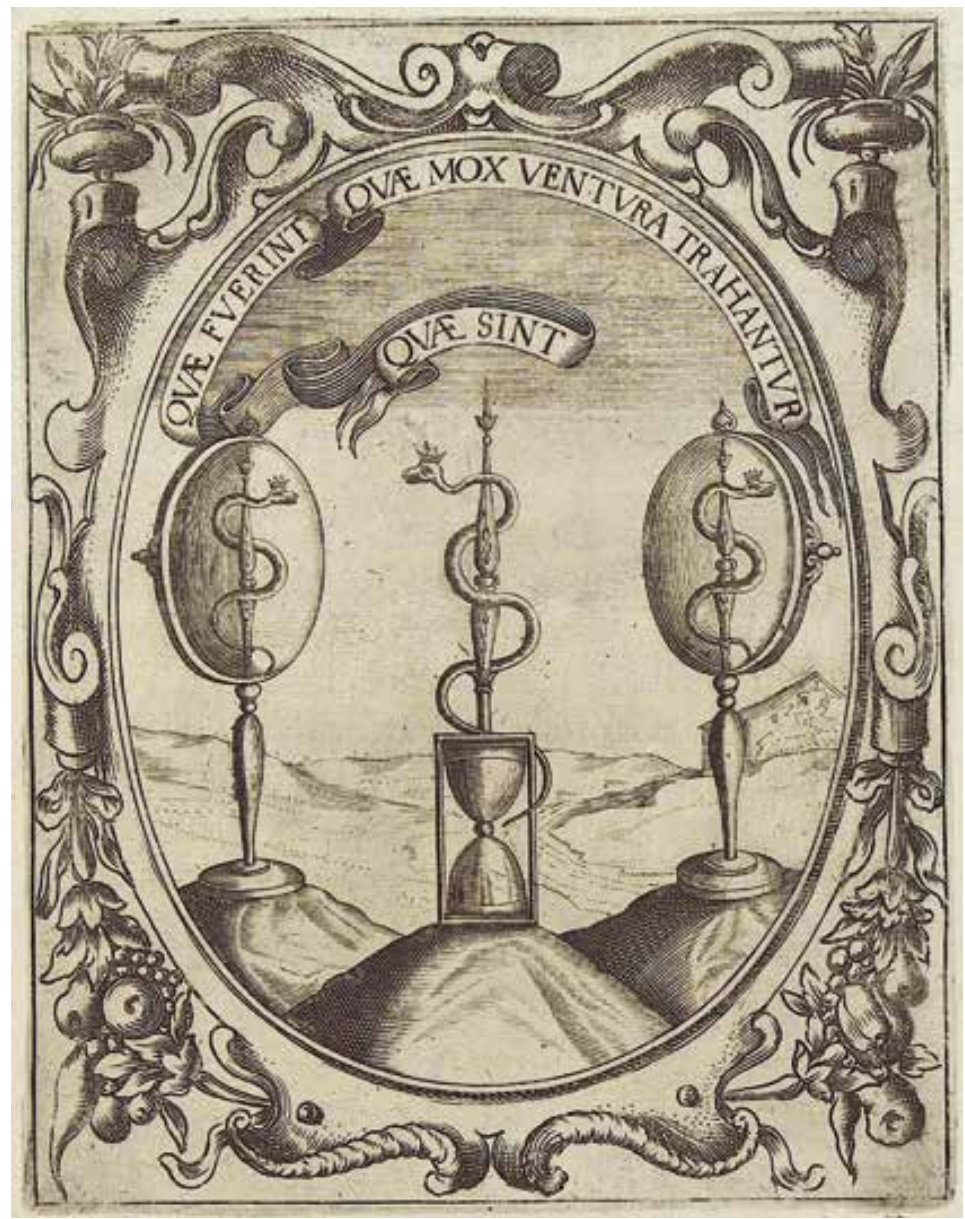

Fig. 12. Qaue sint, quae fuerint, quae mox ventura trahantur (Lo que es, lo que ha sido, lo que pronto será) (1640)

pasado, ordena lo presente y se previene para lo futuro, porque la prudencia a todos tiempos mira» (14-8-1654). Sin duda, esta reflexión de la religiosa trae a la memoria la empresa Quae sint, quae fuerint, quae mox ventura trahantur (Lo que es, lo que ha sido, lo que pronto será), en la que en un montículo central aparece un reloj de arena sobre el que se apoya un cetro con una serpiente coronada enroscada, motivo que se refleja en dos espejos, uno a cada lado [Fig. 12]. Saavedra da a entender que las acciones de gobierno, asistidas de la prudencia, deben realizarse teniendo en cuenta el pasado y considerando el futuro, representados en los dos espejos laterales. 
Otra de las virtudes fundamentales del príncipe es la justicia, acerca de la cual Felipe IV se muestra explícito al reconocer en ella «la piedra fundamental del gobierno» (9-6-1646). Considera la necesidad de administrarla rectamente en sus reinos y de acertar tanto en la distributiva como en la punitiva (4-101651). También sor María asevera que su primera obligación como rey católico es hacer justicia, virtud que «engrandece las Coronas reales y da imperio y potestad a los monarcas» (29-9-1651). En la misma dirección avanza Saavedra, a cuyo juicio la potestad suprema de la monarquía consiste en la correcta administración de la justicia, no en vano «sobre las piedras de las leyes se funda la verdadera política», de manera que en un conjunto de empresas aconseja al príncipe sobre su aplicación. Es el caso de Regit et corrigit ${ }^{37}$ (Rige y corrige), que muestra un freno de riendas de caballería colgado para dar a entender que las leyes han de ser la base de la política y de la razón de Estado, vínculo y freno para el pueblo, al que rigen y corrigen [Fig. 13]. A la justicia dedica también las empresas Praesidia maiestatis (Defensas de la majestad), Pretium virtutis (El precio de la virtud) y Quae tribuunt tribuit (Asigna lo que le asignan), en la que desarrolla su teoría sobre la justicia distributiva. Otras referencias figuran igualmente en las empresas Sin pérdida de su luz, en relación con la distribución de los honores por parte del príncipe, y Col senno e con la mano (Con el pecho y con la mano), en la que insiste en la necesidad de la justicia para el buen gobierno del Estado.

Un príncipe justo será también aquel que sepa gobernar combinando severidad y benignidad a partes iguales; Felipe IV así lo entiende a propósito de la rebelión de Nápoles, al reconocer que debe emplearse la moderación más que la fuerza (21-8-1647). La propia sor María indica la conveniencia de actuar «suavizando a los sujetos con blandura más que con rigor» (16-8-1647); y anima constantemente al monarca a que se conduzca en esta dirección, de manera que «debe gobernar con suavidad y fortaleza, corrigiendo y no acabando» (152-1647). También Saavedra se muestra explícito a este respecto en su empresa Con halago $i$ con rigor, en cuya pictura un potro inclina su cabeza ante la mano de su domador que, a la vez que lo acaricia y peina su copete, lo amenaza con una vara levantada [Fig. 14]; así el príncipe debe educar a sus súbditos combinando severidad y benignidad, para suscitar en ellos amor y temor basados en el respeto.

A la prudencia y justicia se suma la caridad, que desempeña igualmente un relevante papel en los valores del gobernante; el propio Felipe IV no duda en afirmar que «es la basa y fundamento de todas las otras» (2-7-1654). Pero ejercer la caridad en el contexto socioeconómico en el que se desarrolla su reinado no resulta sencillo, por cuanto desde 1640 a las guerras del exterior se sumaron los conflictos interiores, con la sublevación de Cataluña y la

37. Se trata de una de las empresas modificadas en la segunda edición, por cuanto su versión primera presentaba una corona real que encerraba en su interior una espada y una escuadra, acompañada del mote His artibus (Con estas artes). López PozA, «Variantes en las dos portadas y en las picturae», p. 634. 


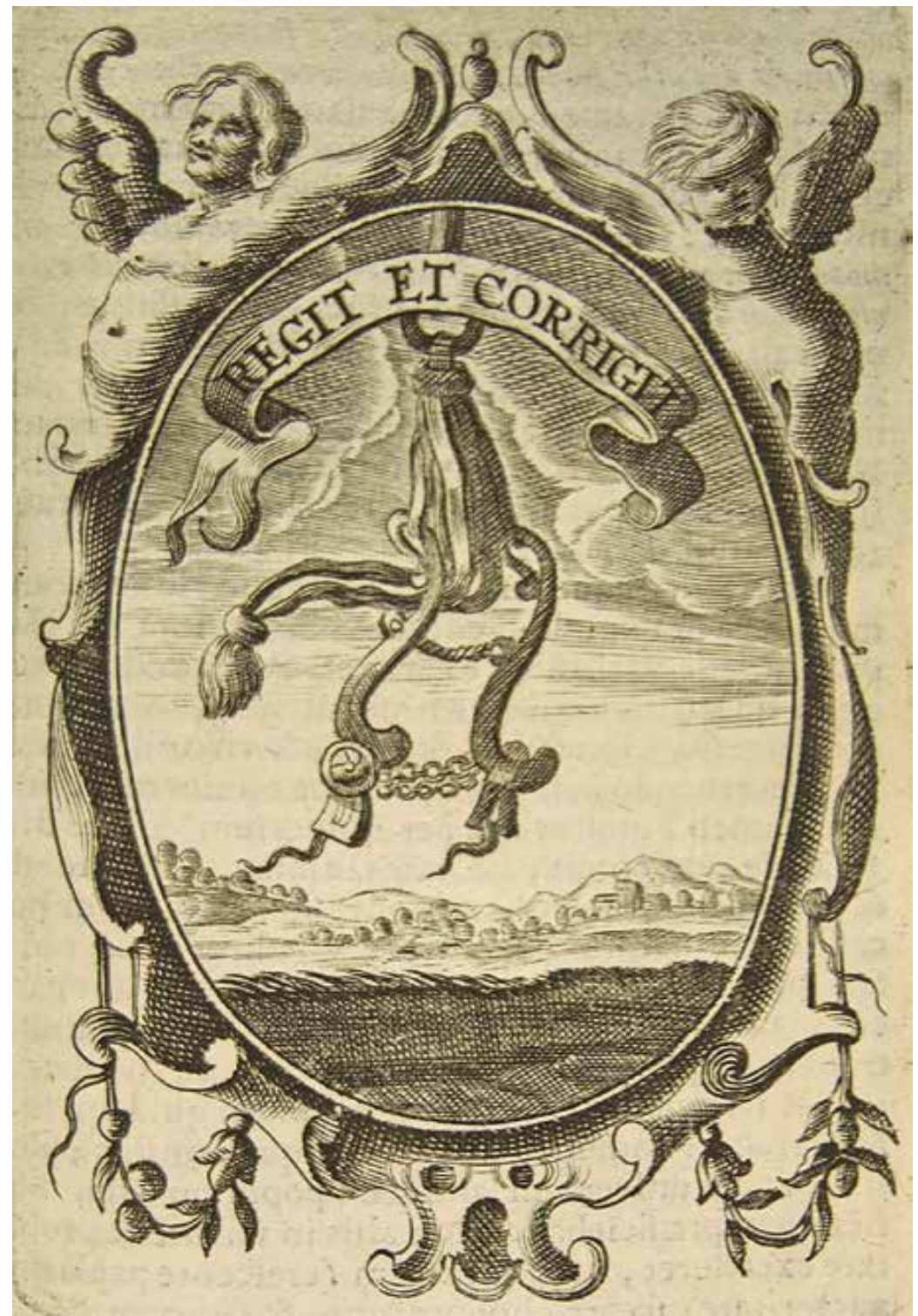

Fig. 13. Regit et corrigit (Rige y corrige) (1659)

proclamación de independencia de Portugal. Estos levantamientos suponen la multiplicación de las necesidades de las tropas y de los problemas para hacer frente a sus pagos, y llevarán a decretar la bancarrota en 1647, suceso 


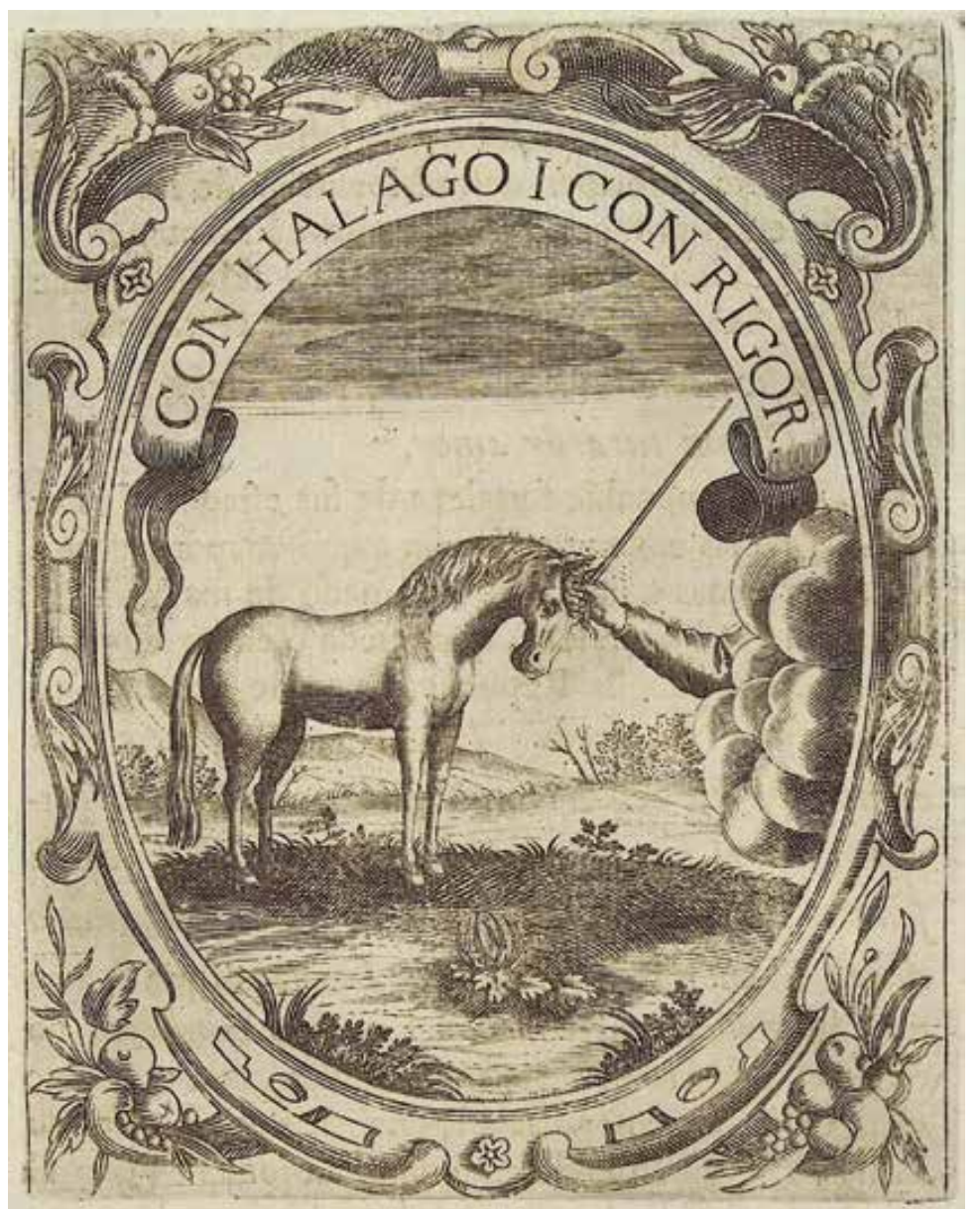

Fig. 14. Con halago i con rigor (1640)

que provocó un torrente de impuestos cuyo número, intensidad y frecuencia aumentaron de forma imparable. ${ }^{38}$

La preocupación por las dificultades económicas del pueblo y por la paz social está presente en el epistolario, que reiteradamente se hace eco de esta inquietud que agrava los problemas esenciales de la monarquía: la guerra complica la situación de los pobres y amenaza el orden establecido. Felipe IV es consciente de una realidad que le quita «muchas horas de sueño» y lamenta

38. Stradling, Felipe IV y el gobierno de España, p. 222. Sobre la grave crisis político-económica de la década de 1640, véase Carmen Sanz Ayán: Los banqueros y la crisis de la Monarquía Hispánica de 1640, Marcial Pons Historia, Madrid, 2013. 


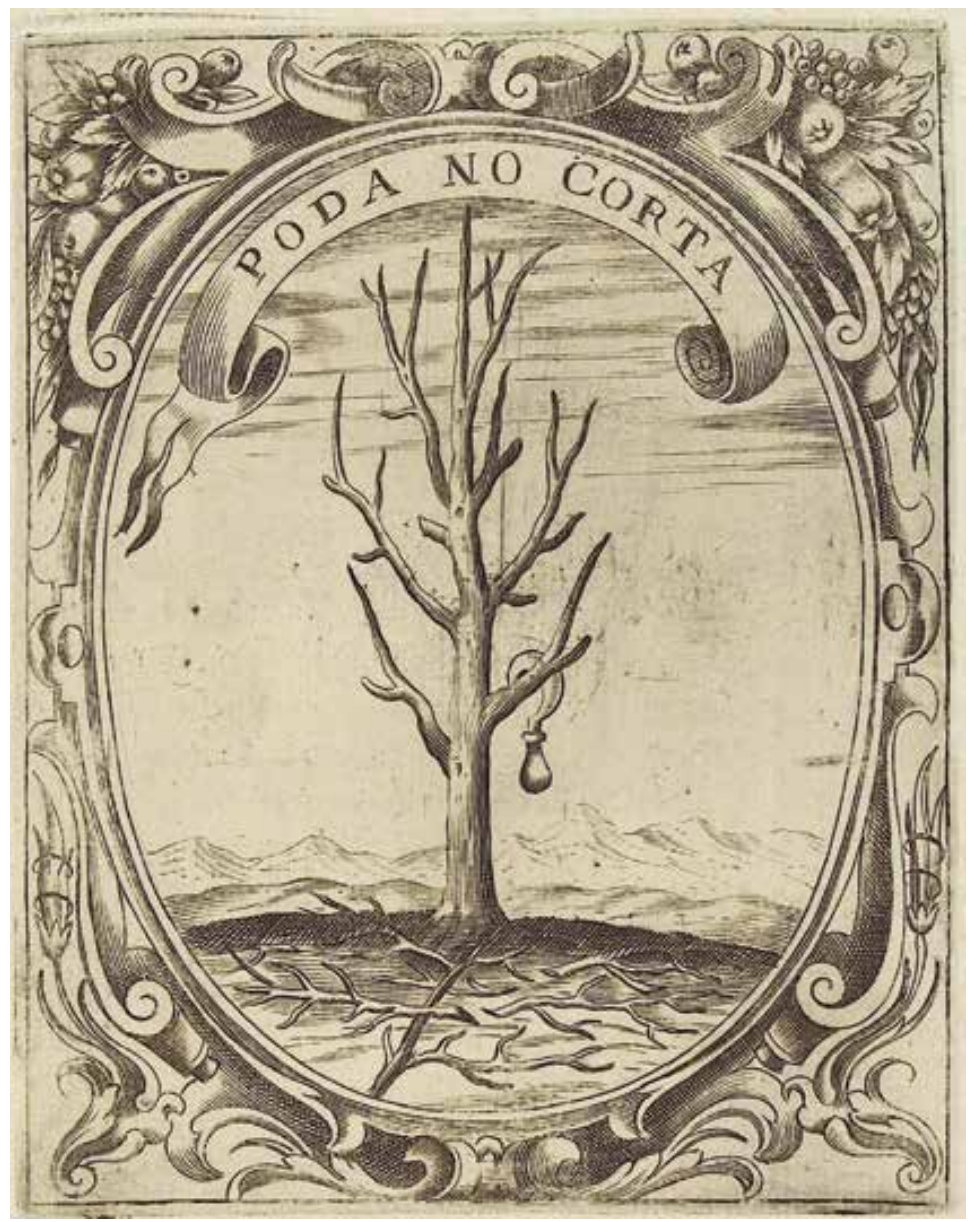

Fig. 15 Poda no corta (1640)

«no poder librar a los pobres de las contribuciones que pagan, aunque lo deseo infinito» (15-7-1648). Desde la caridad tratará de hacer «cuanto es posible para el alivio de los pobres vasallos» (12-6-1652), y procurará cargar con mayores contribuciones a los «ministros y personas que sabemos tienen más hacienda de la que han menester» (27-7-1650). ${ }^{39}$ De igual forma, sor María le ruega que «evite la opresión de los pobres» y que «concurran también los ricos y poderosos» (1-6-1652). Y reflexiona a su vez sobre la avaricia de quienes cobran

39. Ya en 1627, Felipe IV había afirmado ante el Consejo de Castilla que «es mejor gravar con impuestos a los ricos que oprimir a los vasallos pobres de Castilla». Stradling, Felipe IV y el gobierno de España, pp. 276-277. 
tributos que daña gravemente al monarca, por cuanto muchos altercados «no son movidos tanto contra Vuestra Majestad ni sus tributos, cuanto contra las sobrecargas que agravan y echan los ministros, que para cobrar dos hacen gastar cuatro» (30-8-1647).

Las anteriores ideas quedan reflejadas en la empresa Poda no corta, cuya pictura muestra un árbol de cuyas ramas cuelga un podón y, a sus pies, las ramas podadas [Fig. 15], dando a entender que el labrador no corta el árbol cuando necesita leña, sino solo las ramas secas, para que le siga beneficiando en años venideros. ${ }^{40}$ Así, el príncipe debe considerar la cantidad y el tiempo y no explotar a su reino con tributos excesivos, sino mantener el patrimonio para casos de necesidad o para su descendencia. Además, en la imposición de tributos debe caer «el mayor peso sobre los ricos, y queden aliviados los labradores y oficiales, que son la parte que más conviene mantener en la república». Y recuerda al príncipe que el mayor inconveniente de los tributos está en sus cobradores, en muchos casos «usureros que no menos despojan la nave que llega al puerto que el naufragio», por lo que hacen más daño que las mismas cargas; porque, "¿qué mucho que sientan los pueblos las contribuciones, si pagan uno al príncipe y diez a quien las cobra?», concluye.

A los anteriores valores se une el de la religiosidad, tanto en el príncipe como en sus súbditos. En una monarquía asentada sobre la Iglesia -el Hic tutior (Aquí está más seguro) de la empresa saavedriana resulta sumamente explícito-, el monarca deberá actuar con firmeza a la hora de velar por la religiosidad en sus reinos, porque de ello depende su salvaguarda, conforme a la visión providencialista que mezcla los contenidos moral y político; tal es así que Felipe IV no duda en afirmar que «cuanto más ofendemos a Nuestro Señor más armas damos a nuestros enemigos» (7-3-1646). Por ello insiste una y otra vez en la necesidad de «remediar los excesos y los pecados de escándalo» (66-1645); y escribe continuamente a prelados y ministros para que «vigilen por que se guarde la ley divina» (25-5-1650), adoptando medidas eficaces como «único medio para aplacar la ira de Nuestro Señor» (15-2-1646). ${ }^{41}$ En la empresa Immobilis ad immobile numen (Fijo hacia la divinidad firme), Saavedra insiste en la importancia de que el monarca mantenga la unidad religiosa en su reino, asegurando que «más príncipes vemos despojados por las opiniones diversas de religión que por las armas»; en el marco de una Europa carcomida de herejías, considera que los mayores peligros proceden de la escisión religiosa que pueda producirse dentro de un Estado. Para el diplomático, la religión es «el alma de las repúblicas»; de ahí que en la empresa Specie relligionis (Con apariencia de religión) advierta, mediante la imagen

40. Sobre la argumentación recogida por Saavedra en esta empresa, así como en otras que lo revelan como un atento analista económico, véase Rogelio Fernández Delgado: «La emblemática y el pensamiento económico español del siglo xvi y principios del xviı», Estudios de Economía Aplicada, vol. 32-1, 2014, pp. 43-66.

41. Expresiones similares se repiten a lo largo de todo el epistolario, como puede comprobarse en las cartas de 9-10-1645, 18-10-1645, 6-11-1645, 10-7-1647, 9-1-1664, 18-3-1664 y 28-5-1664. 


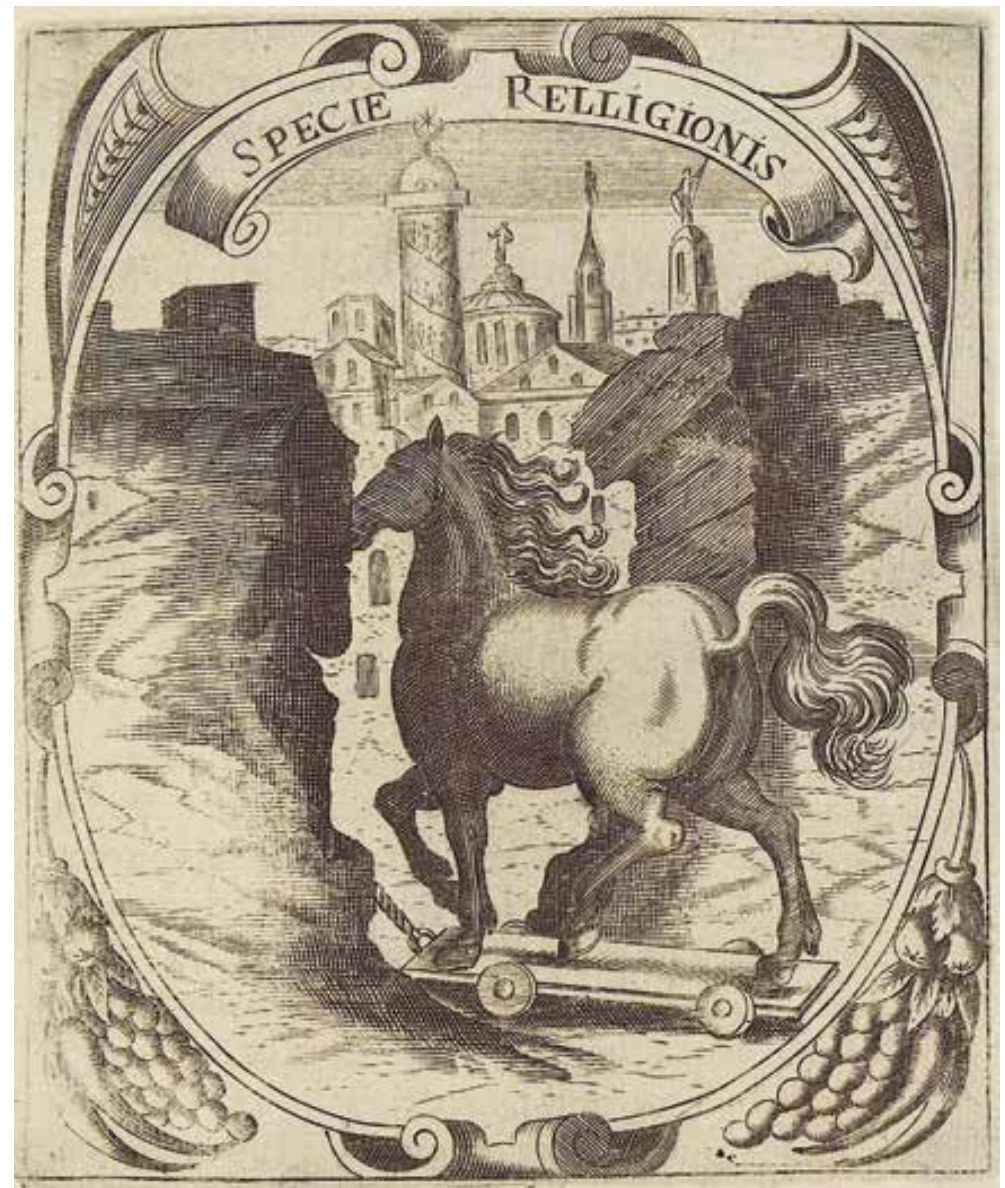

Fig. 16. Specie relligionis (Con apariencia de religión) (1640)

del caballo de Troya que resulta inofensivo en apariencia, del peligro sobre las discusiones de religión que no deben permitirse porque darían lugar a la desintegración de la monarquía ${ }^{42}$ [Fig. 16].

En última instancia, en su conducta como príncipe político-cristiano, Felipe IV tendrá siempre a sus antepasados como modelo a seguir; asílo confiesa a sor María cuando afirma «seguir los ejemplares de mis antepasados, que tan justa y santamente gobernaron estos reinos» (30-1-1647). Son numerosas en sus cartas las alusiones a monarcas pretéritos, fundamentalmente a Carlos V,

42. La idea saavedriana de la religión al servicio de la política es desarrollada por MuriLlo Ferrol, Saavedra Fajardo y la política del Barroco, pp. 191-213. 
de quien alaba su trabajo en defensa de la religión (25-3-1654); y a Felipe II, de quien ensalza su prudencia en el modo de gobernar (30-1-1647) y su labor en la fundación del monasterio de El Escorial (2-11-1648). El mismo argumento emplea Saavedra al recomendar al príncipe que «vuelva los ojos a sus gloriosos progenitores, desde el rey don Fernando el Católico hasta Filipe Segundo, que fabricaron la grandeza desta monarquía», indica en la ya mencionada empresa Quae sint, quae fuerint, quae mox ventura trahantur. Y en parecidos términos se expresa en Purpura iuxta purpuram (La púrpura según la púrpura), en la que figuran sobre una mesa dos piezas de tela teñidas de púrpura, símbolo de la dignidad real, pues para estimar las diferencias han de compararse cosas semejantes [Fig. 17]; así, el príncipe debe contrastar sus virtudes con las de otros antepasados gloriosos, pues tal cotejo será el más seguro maestro para el acierto de su gobierno.

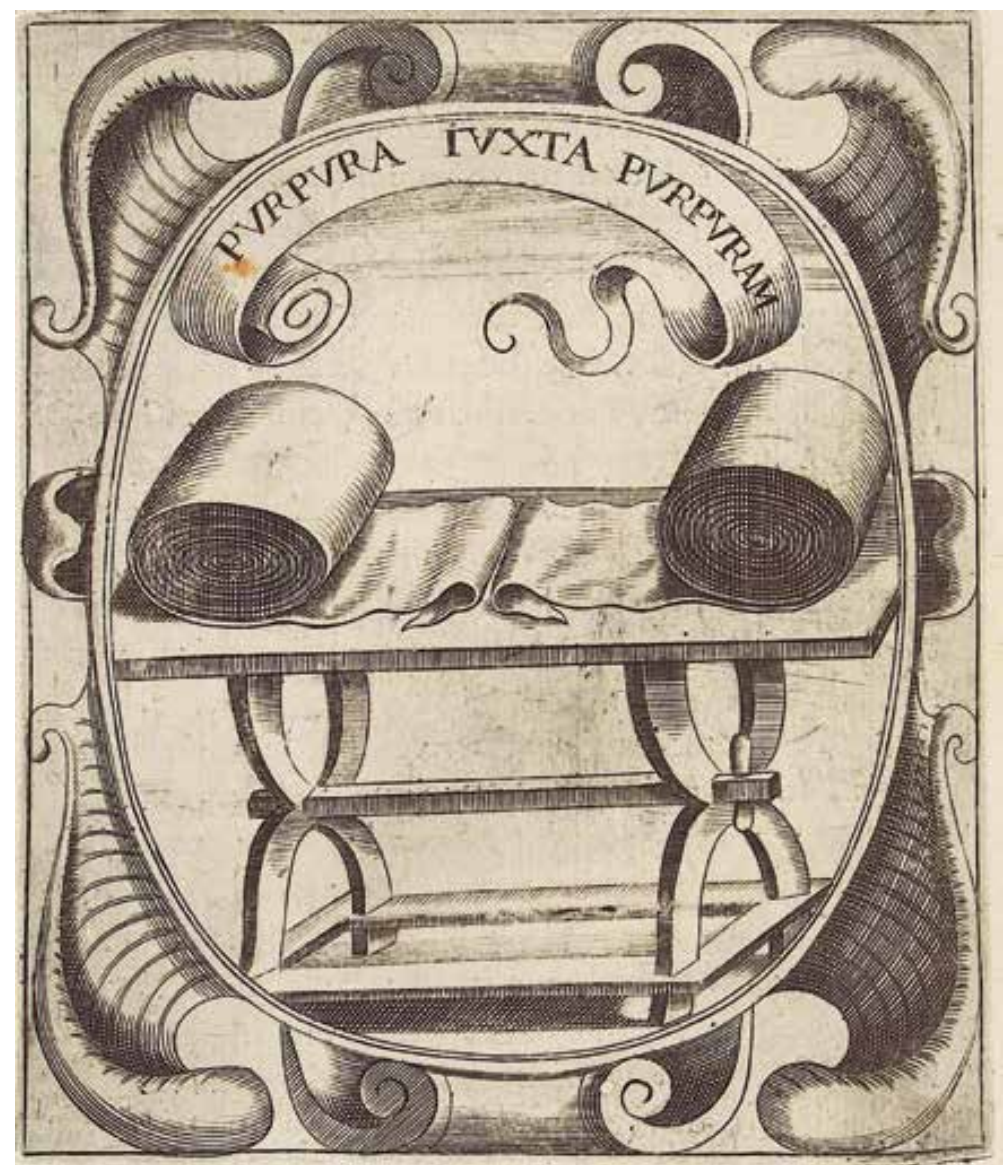

Fig. 17. Purpura iuxta purpuram (La púrpura según la púrpura) (1640) 


\section{EL SISTEMA DE GOBIERNO: LOS MINISTROS Y EL VALIDO}

El sistema de gobierno ocupa un capítulo importante en la correspondencia entre el rey y la religiosa, sobre todo en la década de 1640; el interés y preocupación por el correcto funcionamiento de la monarquía a través del engranaje que conforman los ministros y el valido resulta constante en las cartas de estos años.

Partimos de una realidad incuestionable, como es la necesidad de ministros y consejeros que ayuden al monarca en su tarea de gobierno; el propio Felipe IV lo reconoce al afirmar que la monarquía requiere «ministros así militares como políticos que la gobiernen, pues el Rey, sin ellos, no puede acudir a todo» (29-7-1648). Admitida esta premisa inicial, la sintonía con los ministros resulta fundamental para el buen gobierno, y así, no duda en escucharlos y tener en cuenta sus opiniones: "Oigo a todos los ministros que quieren hablarme, para que tomando más noticias se pueda acertar mejor» (24-9-1645), asegurando a sor María que «tengo la puerta abierta y a nadie que quiere hablarme le niego la entrada» (1-7-1648). ${ }^{43}$ También la religiosa le insta en numerosas ocasiones a escuchar para acertar en sus decisiones, considerando que «entre muchos y buenos pareceres se suele descubrir mejor la verdad» (26-6-1648). Pero, una vez en poder de la información, la decisión final corresponde únicamente al monarca, conducta que asume Felipe IV al afirmar que «habiendo oído primero el parecer de los ministros, en lo más tomo por mí lo último de las resoluciones» (9-1-1647); y poco después repite que «las últimas resoluciones no pasan por otra censura, pues es esto lo que yo entiendo que a mí me toca» (30-1-1647).

Saavedra comparte plenamente el anterior sistema de gobierno, comenzando por la necesidad de ministros que ayuden al monarca en su labor, por cuanto «no hay príncipe tan sabio, que con su ciencia lo pueda alcanzar todo, ni tan solícito y trabajador, que todo lo pueda obrar por sí solo», refiere en su empresa Lumine solis (Por la luz del sol). Para acertar en sus acciones de gobierno, el monarca tiene la obligación de escuchar y dejarse aconsejar, como recoge la empresa His praevide et provide (Con ellos prevé y provee), en la que mediante un brazo cubierto con armadura que sostiene un cetro con tres ojos abiertos incrustados, significa que el príncipe precisa de consejeros que le ayuden en la vigilancia, cuyo consejo le sirva para ser previsor de desgracias y provisor de necesidades [Fig. 18]. El príncipe sensato se dejará aconsejar por sus ministros, pues «los príncipes nacieron poderosos, pero no enseñados. Si quisieren oír, sabrán gobernar». Conviene para ello que «estén siempre abiertas las puertas de los palacios, y no las cierre el príncipe, para que oiga benignamente», concluye en su empresa Omnibus (Para todos). El príncipe

43. También en el epílogo de su traducción de la Historia de Italia, a propósito de su formación en el oficio de rey, Felipe IV asegura «tener los oídos abiertos para todos los que me quisieren hablar en audiencias públicas y particulares, sin negarla a nadie que me la pidiese». Historia de Italia, p. Ix. 


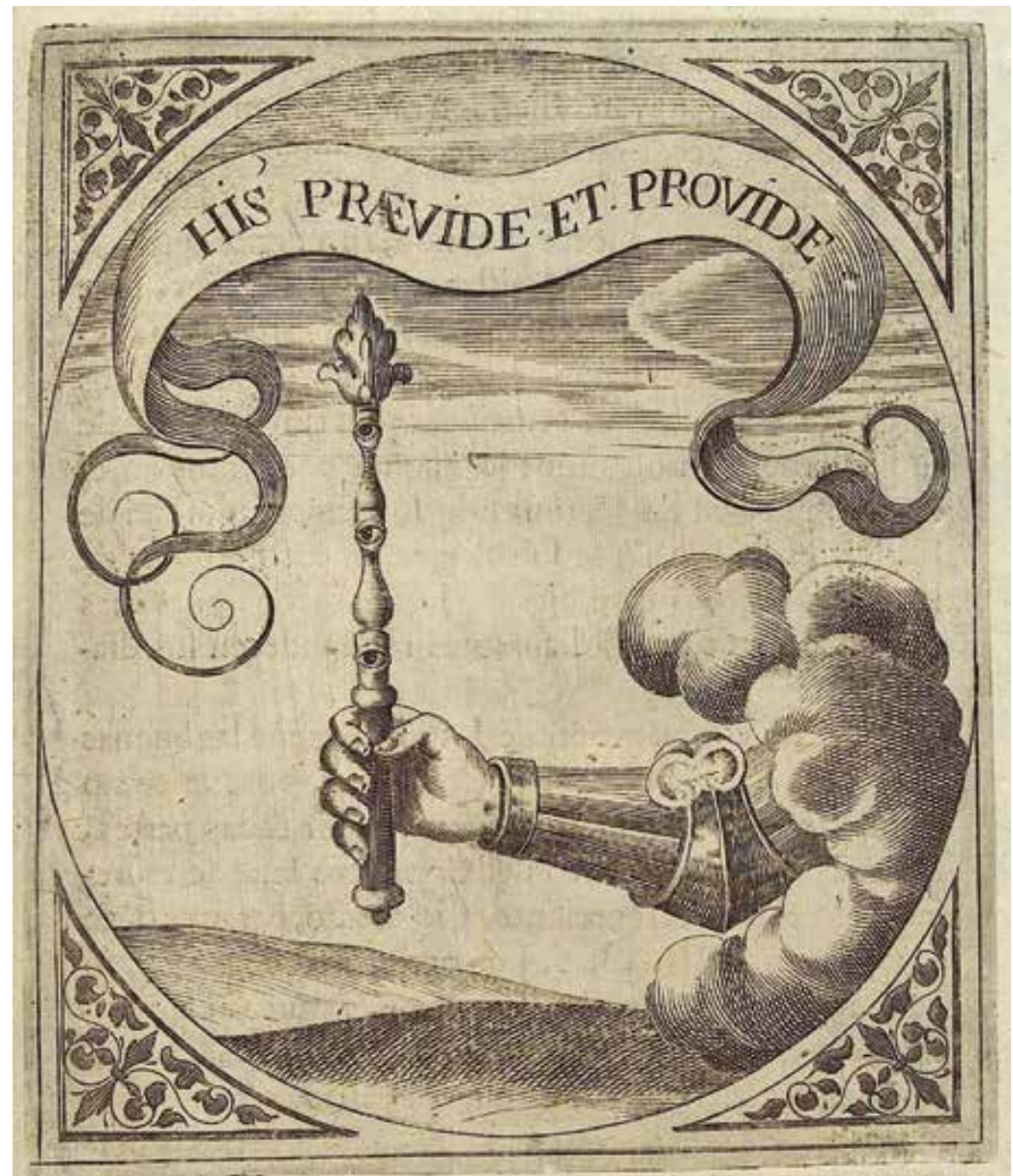

Fig. 18. His praevide et provide (Con ellos prevé y provee) (1640)

escucha el parecer de sus ministros, pero es él quien debe tomar la resolución final; en esta idea insiste en su empresa Uni reddatur (Sea reducido a uno solo), en la que compara la eficacia del gobierno al complejo mecanismo de un reloj de mesa [Fig. 19], pues son los ministros las ruedas o engranajes del interior del reloj de cuyo trabajo depende el funcionamiento del aparato, pero es el príncipe a quien corresponde la toma de decisiones, como manilla del reloj que señala las horas. ${ }^{44}$ 


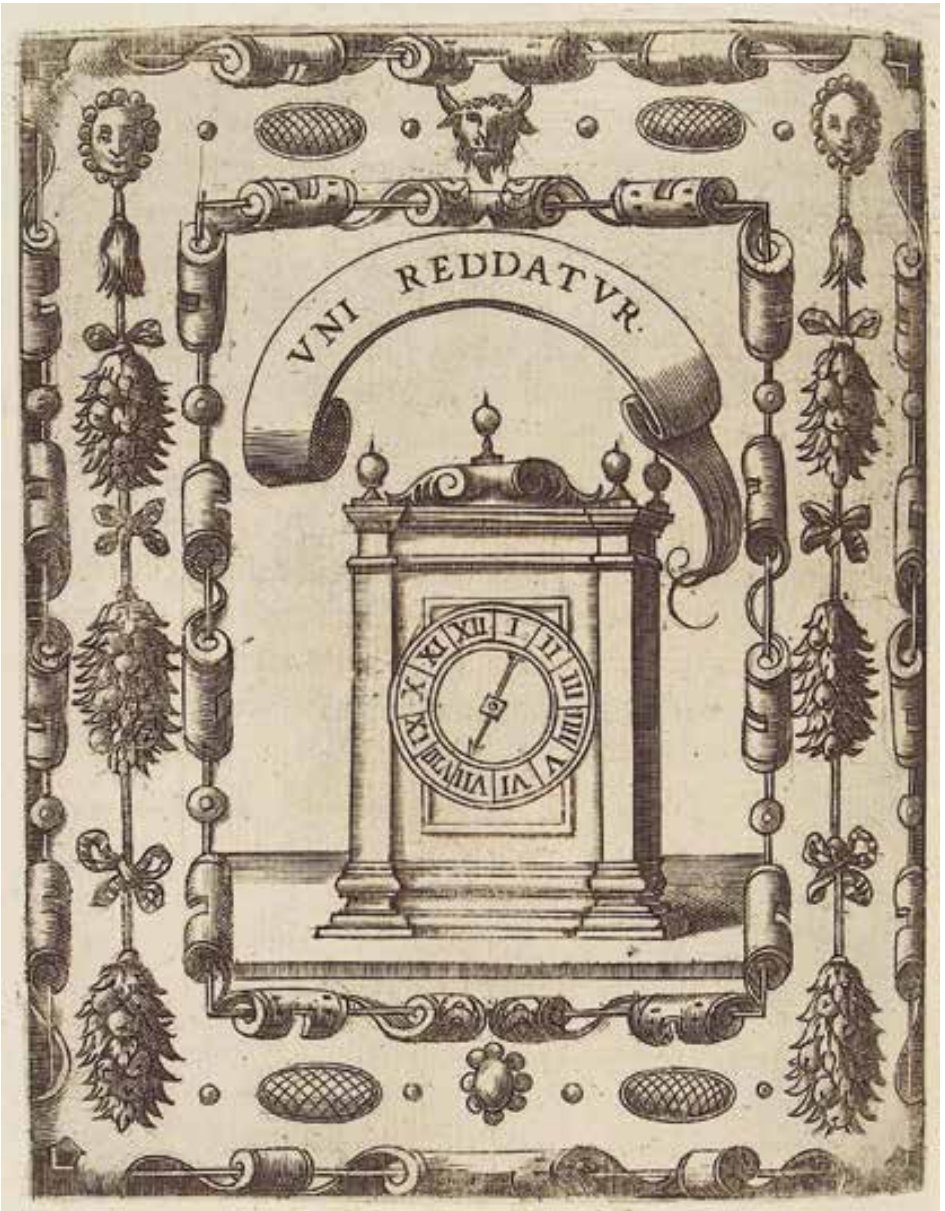

Fig. 19. Uni reddatur (Sea reducido a uno solo) (1640)

Volviendo a la figura del ministro, importa que estos sean virtuosos y velen por los intereses de la monarquía, algo que no parece ajustarse a la realidad. Son continuos los lamentos de Felipe IV, consciente de que «los ministros atienden más a sus intereses propios que a cumplir con su obligación» (6-6-1645). La mayoría se guía por «la ambición y fines particulares» (17-6-1648), confiesa a sor María, quien coincide con el monarca en que «los que gobiernan a España atienden más a los aumentos de sus intereses, que al servicio de Dios y de V.M.» (25-7-1648). El rey procura velar sobre la conducta ejemplar de sus ministros, labor que le resulta harto dificultosa, hasta el punto de admitir que «más me fatigan estas cosas domésticas que las materias generales de la Monarquía» 
(17-6-1648). Es la avaricia el vicio más común, como reconoce abiertamente a sor María al recordar que «bien me habréis oído quejar algunas veces del cuidado que me costaba mirar a las manos a los ministros» (30-1-1647). La imagen entronca con la empresa Custodiunt non carpiunt (Custodian sin beneficiarse), que muestra estatuas del dios Término a la entrada de un jardín, pues al igual que los términos que custodian los jardines no tienen brazos, así los ministros han de vigilar el erario público encontrándose exentos del vicio de la avaricia, que les impulsaría a apropiarse de lo que han de proteger [Fig. 20]. Saavedra recuerda al príncipe que debe evitar la avaricia de sus ministros, pues «donde reina la codicia, falta la paz, aumentan las guerras civiles y caen los imperios». No extraña el desvelo filipino en cortar de raíz tal ambición, dado que, como advierte el emblemista, las consecuencias pueden resultar nefastas.

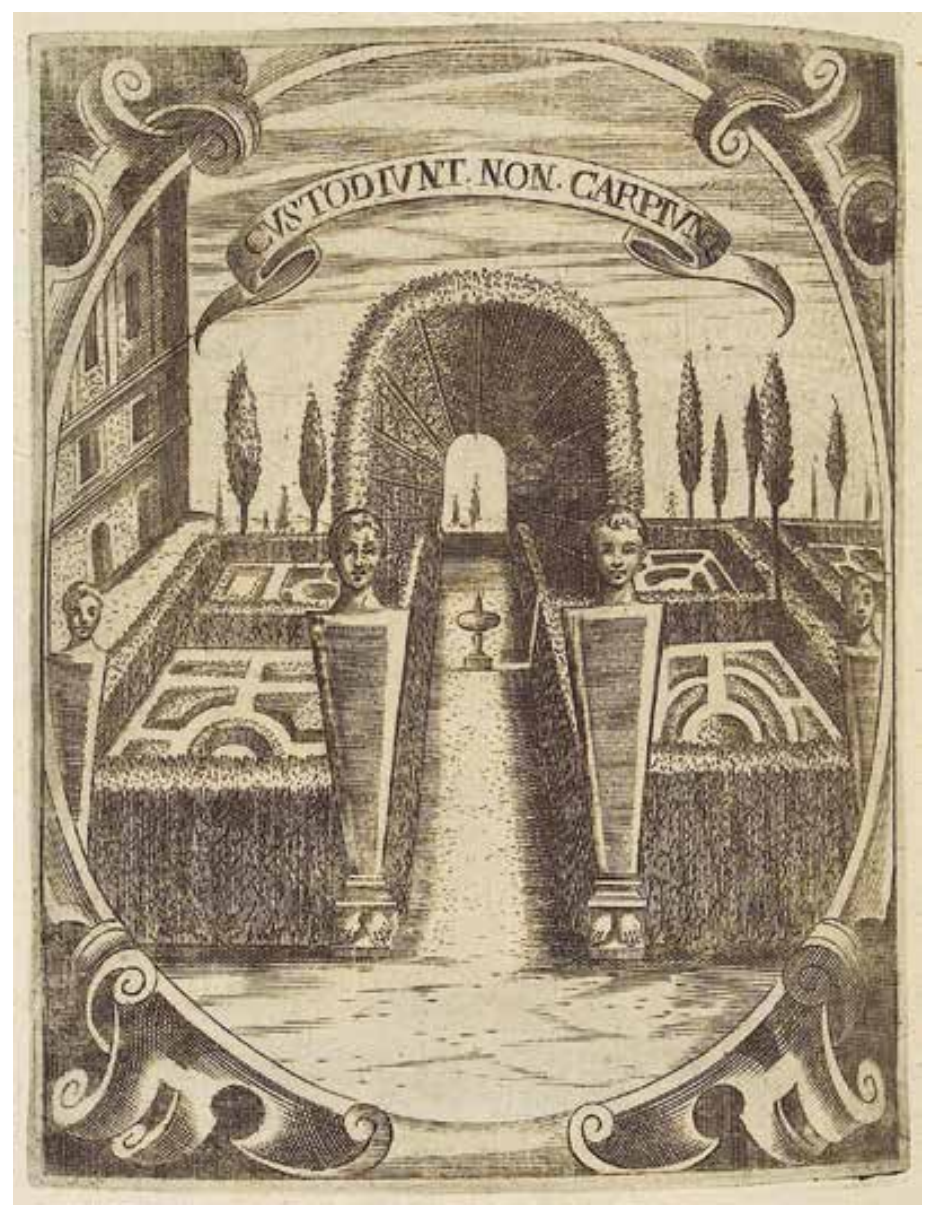

Fig. 20. Custodiunt non carpiunt (Custodian sin beneficiarse) (1640) 
Junto a los ministros, el valimiento resulta capital en el sistema de gobierno de Felipe IV. Sin pretender entrar en la complejidad histórica del asunto, resulta evidente que la caída de Olivares supuso un cambio de política que obligó a Felipe IV a matizar las relaciones valido-monarca. De entrada, el rey manifiesta muy temprano su postura contraria al valimiento tal y como se había planteado hasta ese momento, y su propósito de «apartarme del camino y modo del gobierno pasado»; de tal forma que «aunque no faltan personas que quieran ostentar algún valimiento, viven engañados» (16-10-1643). Sor María alienta esta actitud, recomendando al rey que gobierne sin más ayuda que la de Dios (13-10-1643); no debe compartir su poder con ningún privado, sino estar «como sol entre las estrellas, que a todo lo atiende, y nada le ofende ni le aparta de su grandeza», argumento que reforzará tras las revelaciones del alma del príncipe Baltasar Carlos ${ }^{45}$.

Sin embargo, cuatro años más tarde (30-1-1647), el rey matiza su opinión, de manera que a partir de la experiencia de sus antepasados y de la suya propia, desarrolla toda una teoría en la que no rechaza por completo el valimiento, admitiendo que «tal modo de gobierno ha corrido en todas cuantas Monarquías, así antiguas como modernas, ha habido en todos los tiempos, pues en ninguna ha dejado de haber un ministro principal de quien se valen más sus dueños». Siguiendo el ejemplo de Felipe II, defiende la existencia del valido, pero realiza a su vez dos reflexiones al respecto: primera, su elección deberá recaer en persona íntegra que acredite virtudes y capacidad para el cargo; de ahí el nombramiento de don Luis de Haro, quien «desde muchacho se crió conmigo y nunca he reconocido en él cosa fea ni en las costumbres ni en lo que me ha representado»; segunda, el rey nunca soltará las riendas de la toma de decisiones, gobernando «sin dar al ministro más de lo que le toca»; es decir, la figura del valido queda alejada del carácter plenipotenciario de la época de Olivares y no gozará del control absoluto del poder. ${ }^{46}$

En sus líneas maestras, la política de Felipe IV en materia de valimiento coincide con la propuesta por Saavedra en Lumine solis (Por la luz del sol), que muestra un cielo estrellado en el que brilla la luna en su fase de cuarto menguante [Fig. 21]; quiere dar a entender que el valido (luna) y los ministros (estrellas) no brillan con luz propia, sino prestada del príncipe (sol), que debe elegirlos bien y

45. Sobre la oposición de sor María al valimiento y su animadversión hacia «el dedo malo», como denomina a don Luis de Haro en su correspondencia con Francisco de Borja, reflexionan Morte Acín, Misticismo y conspiración, pp. 299-313; y MARTínez Millán, «Política y religión», pp. 1394-1428.

46. Afirma Stradling que, en realidad, tras la caída de Olivares se produce la abolición efectiva del valimiento como instrumento de gobierno, por cuanto don Luis de Haro nunca reunió las condiciones necesarias para poder ser calificado como tal, teniendo más en común con los poderosos secretarios reales de Felipe II que con la posición dominante alcanzada por los únicos validos verdaderos (Lerma y Olivares). Stradling, Felipe IV y el gobierno de España, pp. 371-380. Contrario a esta opinión se muestra Gambra, para quien Haro desempeñó un valimiento similar al de los dos citados, eso sí, matizado por la moderación y el disimulo. Andrés Gambra GutiérRez: «Don Luis Méndez de Haro, el Valido encubierto», en JosÉ Antonio Escudero (coord.): Los Validos, Universidad Rey Juan Carlos y Editorial Dykinson, Madrid, 2004, pp. 277-309. 


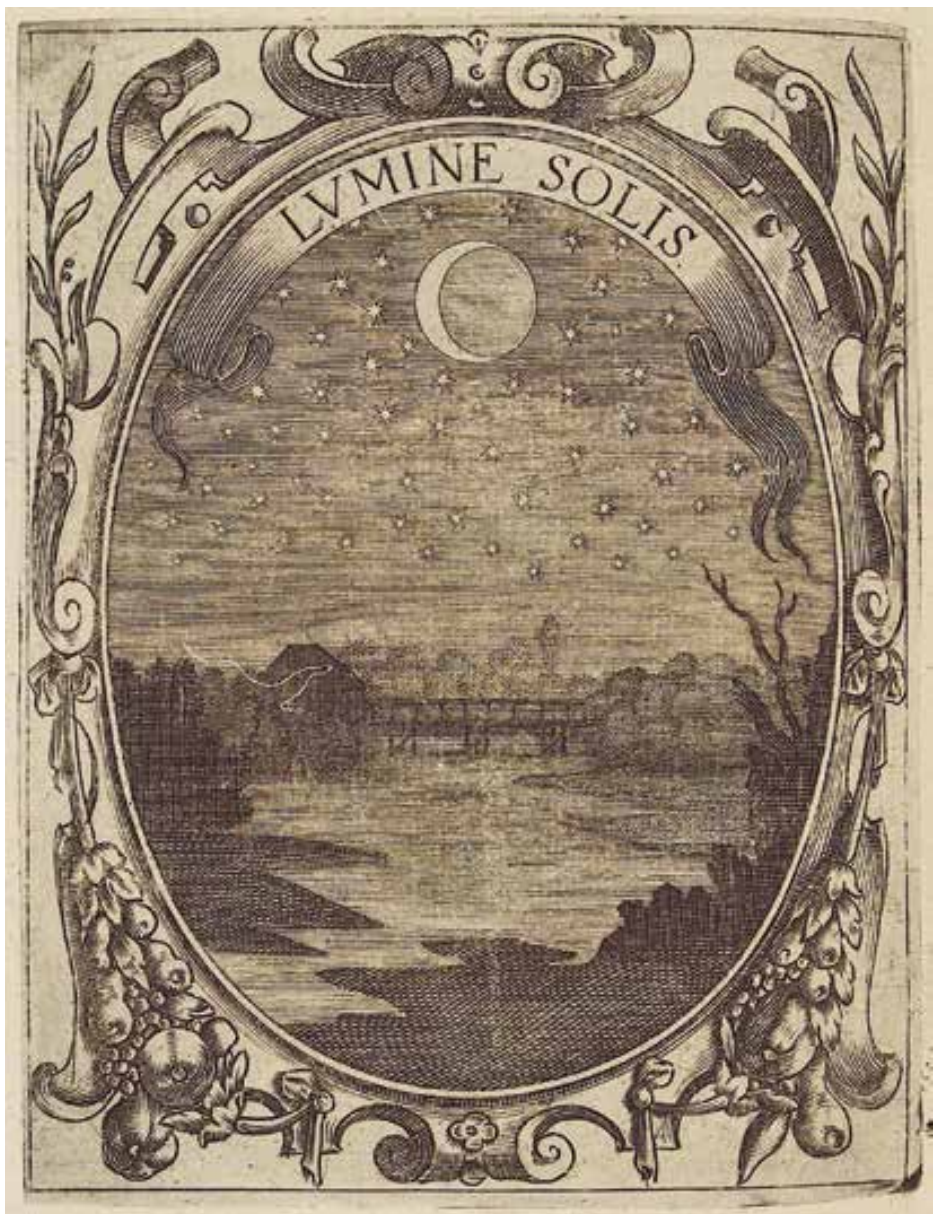

Fig. 21. Lumine solis (Por la luz del sol) (1640)

en quienes no conviene que deje todo el gobierno, sino solo aquello que exceda a sus fuerzas. Saavedra coincide con el rey en la conveniencia de «que se halle cerca del príncipe algún ministro que oiga y refiera, siendo como medianero entre él y los vasallos». Pero admitida esta necesidad plantea, al igual que el monarca, dos consideraciones al respecto: primera, el príncipe debe acertar en su elección, valorando los méritos y lealtad del candidato; segunda, nunca le concederá más poder del necesario para desarrollar su labor, "porque si todo se lo entrega, le entregará el oficio de príncipe», de ahí que el valido deba 
obrar «como sombra, no como cuerpo». ${ }^{47}$ Las apreciaciones sobre la conducta del valido continúan en la empresa Iovi et fulmini (Con Júpiter y sus rayos), un verdadero tratado sobre el valimiento que concluye con una advertencia al príncipe acerca de los riesgos que entraña este modelo de gobierno.

En el sistema de gobierno filipino debemos abordar un último punto: ¿qué papel desempeñó sor María? Diversos investigadores sostienen que actuó como privado en el sentido político de la palabra, insistiendo en que la monja dirigía la monarquía desde su celda. ${ }^{48} \mathrm{Si}$ fue realmente así, Felipe IV estaría contraviniendo a Saavedra, quien en su empresa Fulcitur experientiis (Sustentada en las experiencias), desaconseja al monarca acudir a religiosos como consejeros políticos, porque en ellos no está seguro el secreto y solo convienen para consejos espirituales.

Sin embargo, y sin negar que la relación de Felipe IV con sor María adquirió dimensión política, no parece ser que ostentara un valimiento efectivo. ${ }^{49}$ Las razones por las que el rey comienza la correspondencia se explican ya en su primera carta: «Acudo a vos para que cumpláis la palabra que me disteis de clamar a Dios para que guíe mis acciones y mis armas» (4-10-1643). Felipe IV busca en ella consejo y consuelo espiritual, circunstancia en absoluto excepcional para la mentalidad de la época; ${ }^{50}$ la considera intercesora válida ante Dios tanto en el terreno personal como político, de manera que le comunica los hechos por cuyo buen suceso debe orar al Señor. ${ }^{51}$ Lo cierto es que nunca pidió directamente su opinión sobre los grandes problemas que tuvo que re-

47. A propósito de esta expresión, no estará de más recordar la frase contenida en el discurso del condeduque en las Cortes del Buen Retiro el 17-1-1639, cuando afirmaba que "yo, como sombra y eco de Su Majestad y como polvo de sus reales pies, no tengo dictamen sino seguir el suyo». Marañón, El condeduque de Olivares, pp. 447-448.

48. Sánchez de Toca afirma que, salvo la experiencia política, sor María reunía en alto grado todas las demás cualidades que adornan al buen consejero de príncipes; Marañón abunda en la misma teoría al considerar que la religiosa fue «su valido y no solo su espiritual consejera»; idéntica postura mantiene Vilahomat, a cuyo juicio desde la voz firme que dictaba en nombre de Dios, orientó al rey en decisiones políticas, económicas y militares; y Martínez Millán asevera que mantuvo una influencia social y política equiparable a la de cualquier gran patrono cortesano, interviniendo en las pugnas por conseguir el poder y la gracia real, no en vano estaba plenamente informada de lo que acontecía en la corte. SÁNCHEZ DE TOCA, Felipe IV y Sor María de Ágreda, pp. 154-157; Marañón, El conde-duque de Olivares, pp. 237-238; José Vilahomat: «Sor María de Jesús Ágreda: La autoridad de la fe», Lemir, 8, 2004 (http://parnaseo.uv.es/ Lemir/Revista.html); MARTínez MiLláN, «Política y religión», p. 1378.

49. Esta es la postura mayoritaria que adoptan, entre otros, PÉREZ VILlAnUeVA, «Sor María de Ágreda y Felipe IV», p. 372; LuIs GARCía Royo: La aristocracia española y sor María Jesús de Ágreda, Espasa-Calpe, Madrid, 1951, pp. 204-233; STRAdLing, Felipe IV y el gobierno de España, pp. 387-391, quien reconoce no obstante cierta influencia ejercida por sor María en la política de Felipe IV a propósito de su intransigencia en el tema de Portugal; y Morte Acín, Misticismo y conspiración, p. 346, al aseverar que los consejos de la religiosa, lejos de influir en la política del monarca, iban encaminados a reconfortarlo espiritualmente, si bien observa una mayor insistencia en los de tipo militar que presuponen determinados conocimientos provenientes de su círculo de amistades.

50. Las consultas de reyes y políticos a religiosas constituyeron un hecho más frecuente de lo que en un principio pudiera imaginarse en otras cortes y estados europeos, también de la casa de Austria, como pone de manifiesto María Pilar MANERo Sorolla: «Visionarias reales en la España Áurea», en Agustín REDONDo (ed.): Images de la femme en Espagne aux XVI et XVII siècles, Publications de la Sorbonne, París, 1994, pp. 305-318.

51. Correspondencia con Felipe IV, pp. 31-32. 
solver; y, salvo excepciones puntuales, tampoco sor María prodiga consejos precisos, sino apoyo moral, peticiones de confianza en la ayuda divina, e invitaciones a la justicia del gobierno y a la reforma moral de la conducta regia. De hecho, es difícil encontrar en el epistolario consejos que se concreten en decisiones de gobierno; y cuando se atreve a dar su opinión, en muchos casos el monarca hace caso omiso de ella, tanto en el tema del valimiento como en asuntos de guerra.

\section{LA POLÍTICA MILITAR DE LA MONARQUía}

Todas y cada una de las acciones del monarca en materia de política militar van encaminadas a un fin único y primordial: el logro de la paz, a la que Felipe IV considera «el negocio de los negocios» (1-6-1656). En su anhelo de paz coincide con sor María, quien aboga por lograrla aun cediendo en ella, «pues lo que fuere V. M. de pródigo dejando intereses por la paz, se los dará Dios por otros caminos» (14-8-1645). ${ }^{52}$

La paz es el mayor bien al que aspira la cristiandad, y como tal asoma a lo largo de todo el epistolario; pero también lo hace la guerra, en un momento en el que la monarquía española se bate en varios frentes. Uno de los temas que continuamente se plantea en la correspondencia es: ¿hasta qué punto están justificadas las guerras emprendidas contra los príncipes cristianos? Felipe IV responde a esta pregunta con un doble razonamiento. El primero es que van encaminadas únicamente a lograr la paz, y en ningún momento tienen ánimo de conquista o engrandecimiento. El segundo -que desarrolla con mayor profundidad a propósito de la confrontación con Francia declarada abiertamente en 1635 por el Manifiesto de Luis XIII- es que se trata de una guerra que él no ha iniciado, a través de la cual trata de recuperar lo que se le ha usurpado; considera la guerra con Francia una guerra justa que le ha sido impuesta, y por tanto «defensiva, santa y religiosa», como la calificó un propagandista..$^{53}$ Así lo notifica a sor María al confesarle que fue provocada por el rey francés «entrando en Flandes con grandes fuerzas, uniéndose con aquellos rebeldes y herejes contra mí» (20-7-1645); y solicitándole que ruegue al Señor «que consigamos la recuperación de lo usurpado injustamente en esta

52. El tema de la paz es introducido por sor María en 1645, coincidiendo con las negociaciones en Münster para cerrar la Guerra de los Treinta Años, de las que tendría noticia. Morte Acín, Misticismo y conspiración, p. 376.

53. Stradling, Felipe IV y el gobierno de España, p. 391. Acerca del origen del conflicto con Francia, Felipe IV afirmaba que la responsabilidad no recaía en él, sino en el rey francés que sin previo aviso entró en Flandes y se alió con los rebeldes. Ana Morte Acín: «La política exterior de la Monarquía Hispánica en la correspondencia de Felipe IV con Sor María de Ágreda», en Porfirio Sanz Camañes (ed.): Tiempo de cambios. Guerra, diplomacia y política internacional de la Monarquía Hispánica (1648-1700), Actas, Madrid, 2012, p. 146. Sobre la postura saavedriana en este asunto, véase SolEDAD ARREDONDO SirodeY: «La polémique de 1635: José Pellicer et Diego Saavedra Fajardo», en Robin LefERE y MERCEDES Boixareu Vilaplana (coords.): L'histoire de la France dans la littérature espagnole, Honoré Champion, Paris, 2011, pp. 263-288. 


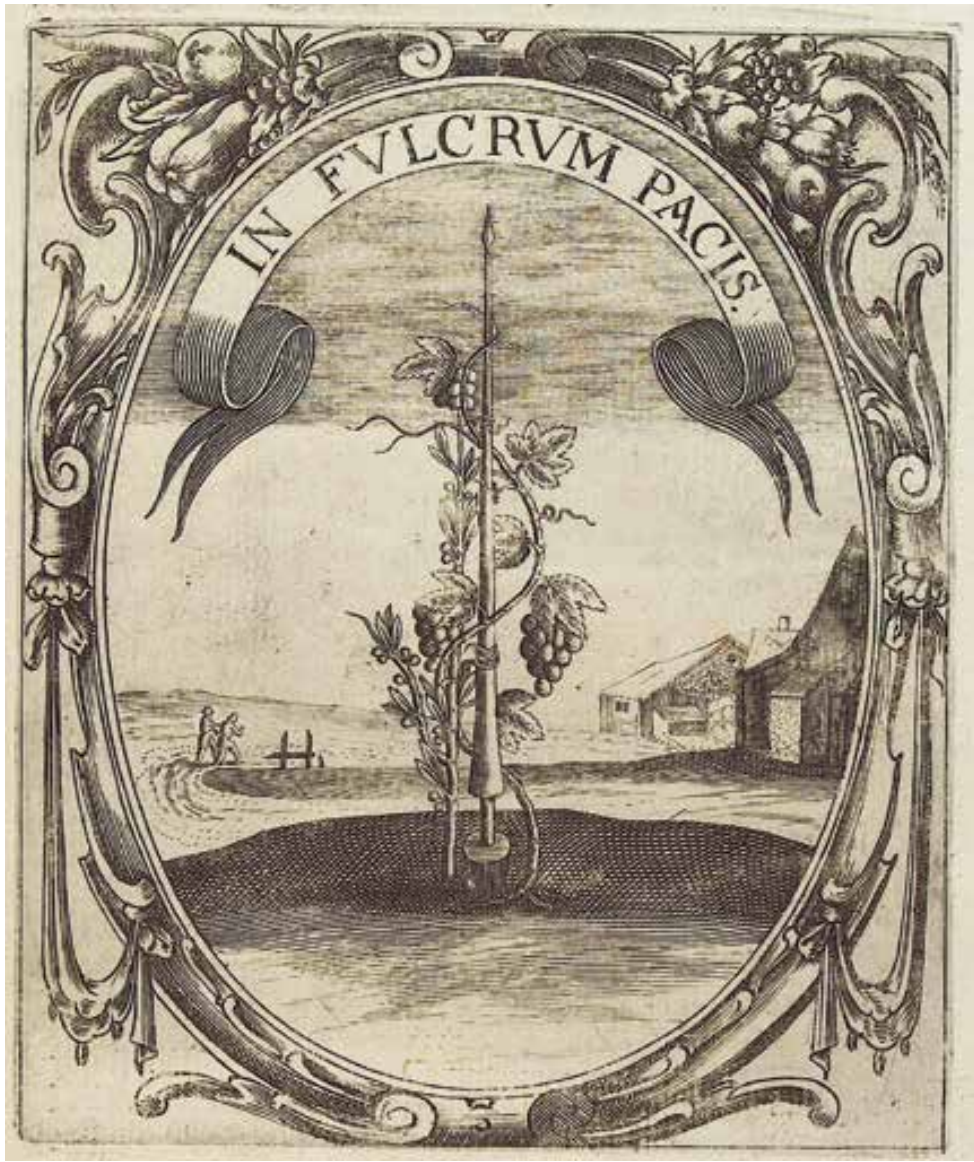

Fig. 22. In fulcrum pacis (En apoyo de la paz) (1640)

monarquía y la paz de la Cristiandad» (28-9-1650). Los argumentos del monarca convencieron a sor María, quien, pese a mostrarse contraria a la guerra entre príncipes cristianos, acabará por reconocer la justicia del enfrentamiento con Francia al admitir que «las guerras de su Corona son justas, pues quiere paces y no las admiten, y defiende V. M. lo que es suyo en propiedad» (10-7-1648).

El planteamiento filipino en materia de guerra entronca directamente con el pensamiento de Saavedra; así, la idea de que la guerra solo se justifica para mantener la paz se convierte en un verdadero adagio que se repite aquí y allá en las Empresas. ${ }^{54}$ Significativa es al respecto Merces belli (La recompensa de la

54. Christian Bouzy: «Saavedra Fajardo, diplomático y educador del príncipe», Empresas políticas, n. ${ }^{\circ}$ 7, 2006, pp. 141-142. 


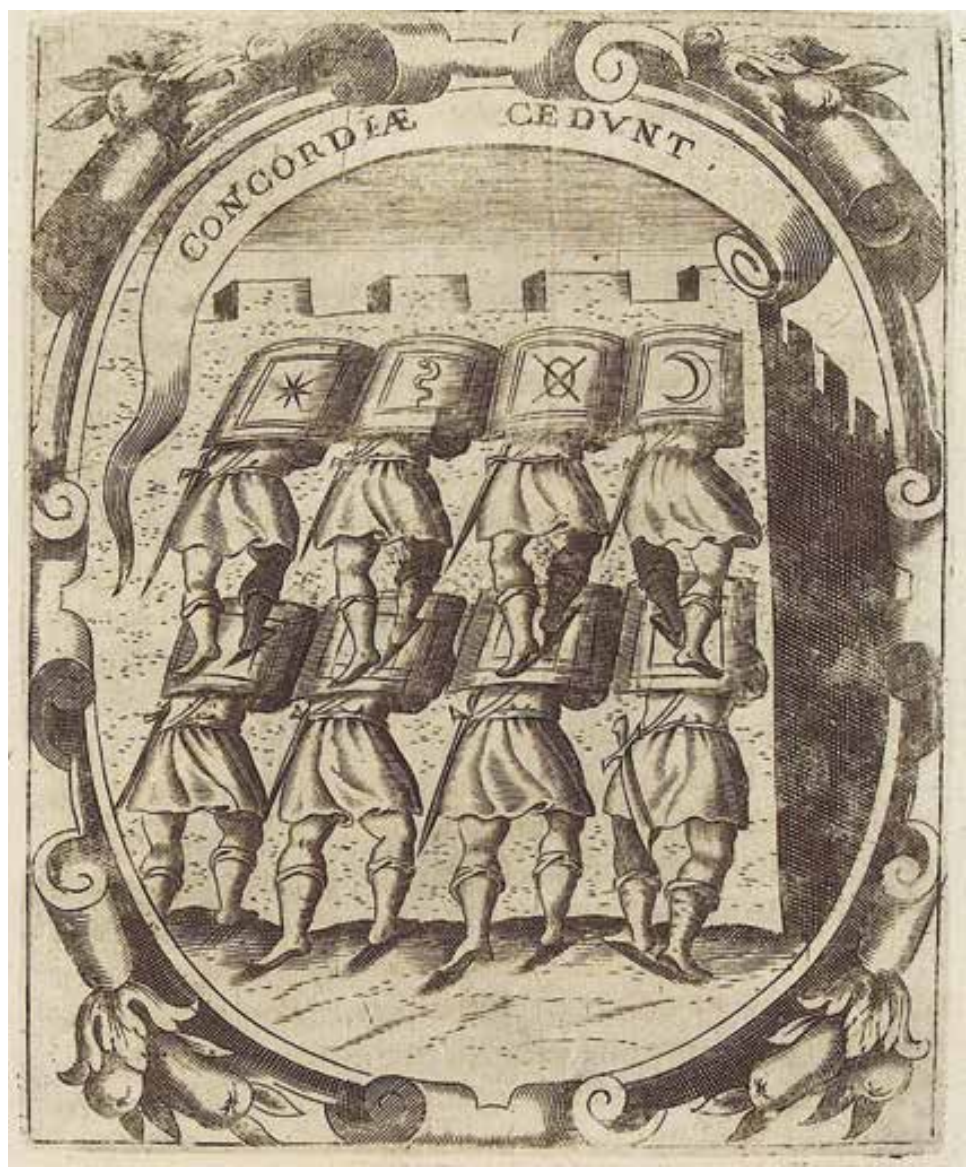

Fig. 23. Concordiae cedunt (Ceden a la concordia) (1640)

guerra), en la que mediante la imagen del león muerto que yace en el suelo y en cuya boca las abejas fabricaron un panal de miel, sostiene que solo para sustentar la paz tiene sentido la guerra. Estrecha relación mantiene igualmente con In fulcrum pacis (En apoyo de la paz), cuya pictura muestra una lanza clavada en tierra por la que trepan una vid y una rama de olivo, dando a entender que el reino que tiene reputación de ser fuerte en la guerra se conserva próspero y en paz [Fig. 22]; afirma Saavedra que la guerra no debe buscarse, y tan solo resulta legítima cuando interviene una causa justa como es mantener el Estado propio o tratar de recuperar el usurpado. Resulta evidente el paralelismo entre el pensamiento del monarca y el del diplomático murciano, al que se suma sor María cuando en vísperas de la Paz de los Pirineos escribe: «Ninguna guerra 
es lícita entre los príncipes cristianos sino la defensiva, y ésta ha de ser a más no poder y sin haber principiado primero» (11-4-1659).

A los conceptos de guerra y paz van íntimamente ligados en el epistolario otros dos términos, concordia y discordia, buscando la primera entre los príncipes cristianos para hacer frente al enemigo común, y alimentando la segunda en las potencias enemigas para debilitar sus fuerzas.

En diversas cartas de 1645 y 1663-64, el rey insiste en la concordia para asegurar la defensa de la cristiandad, afirmando que «el punto más principal para impedir los progresos del Turco es que nos unamos los príncipes cristianos» (4-9-1645). ${ }^{55} \mathrm{Tal}$ idea es secundada con entusiasmo por sor María, quien plantea un proyecto con ánimo de cruzada al sostener que «deben los príncipes católicos unirse, hacer paces y armarse contra los herejes, dejar su propia causa terrena y defender la de Dios» (17-2-1656). La llamada a la concordia de ambos se encuentra en sintonía con la empresa Concordiae cedunt (Ceden a la concordia), en la que ocho soldados romanos emplean el sistema de la tortuga militar para escalar una fortaleza almenada [Fig. 23]; así el príncipe debe aprender que la ayuda mutua y la concordia son capaces de vencer los mayores obstáculos.

Por el contrario, Felipe IV rechaza la concordia con el Turco, pues «nunca hemos tenido paz con ellos, ni con la ayuda de Dios la tendré» (23-8-1645); actitud muy diferente a la de Francia, razón por la cual sor María implora a la justicia divina que «rinda y humille» a los franceses (1-9-1645). La cuestión de la alianza con los herejes, utilizada por Francia, es objeto de la empresa Impia faedera (Alianzas impías), en la que Saavedra la equipara al Vesubio, amigo traicionero del Tirreno que, engañado por sus verdes laderas, ve salir el fuego de sus entrañas cuando menos lo espera [Fig. 24]; «no espere menos daños el príncipe católico que se coaligare con infieles», sentencia el diplomático, quien asevera que la justicia divina castigará el atrevimiento galo, pues «se puede inferir cuán enojado está Dios contra el reino de Francia por las confederaciones presentes con herejes para oprimir la Casa de Austria».

La idea de discordia está relacionada con los disturbios de la Fronda, que sacudieron Francia entre 1648 y 1653, e hicieron soñar a Felipe IV con una vigorosa recuperación frente al país vecino. ${ }^{56}$ Muy pronto el monarca da noticia a sor María de la beneficiosa situación para sus intereses, a la vez que atisba un rayo de esperanza, por cuanto «si esto fuera cierto y se continuase, podía ser medio para facilitar la paz que tanto deseo» (3-2-1649). A la vista de los acontecimientos, trata de alimentar las discordias para aprovecharse de su debilidad y forzarla a pedir la paz, informando a la religiosa de que «las cosas de Francia están cada día más revueltas, y mi ejército ha entrado allá para darlas

55. Véanse a este respecto las cartas de 7-8-1645, 23-8-1645, 27-11-1663, 9-1-1664 y 18-3-1664

56. Sobre la postura de Felipe IV y sor María a propósito de los conflictos internos de Francia, véase Morte Acín, Misticismo y conspiración, pp. 369-375; y «La política exterior de la Monarquía Hispánica», pp. 154-156. 


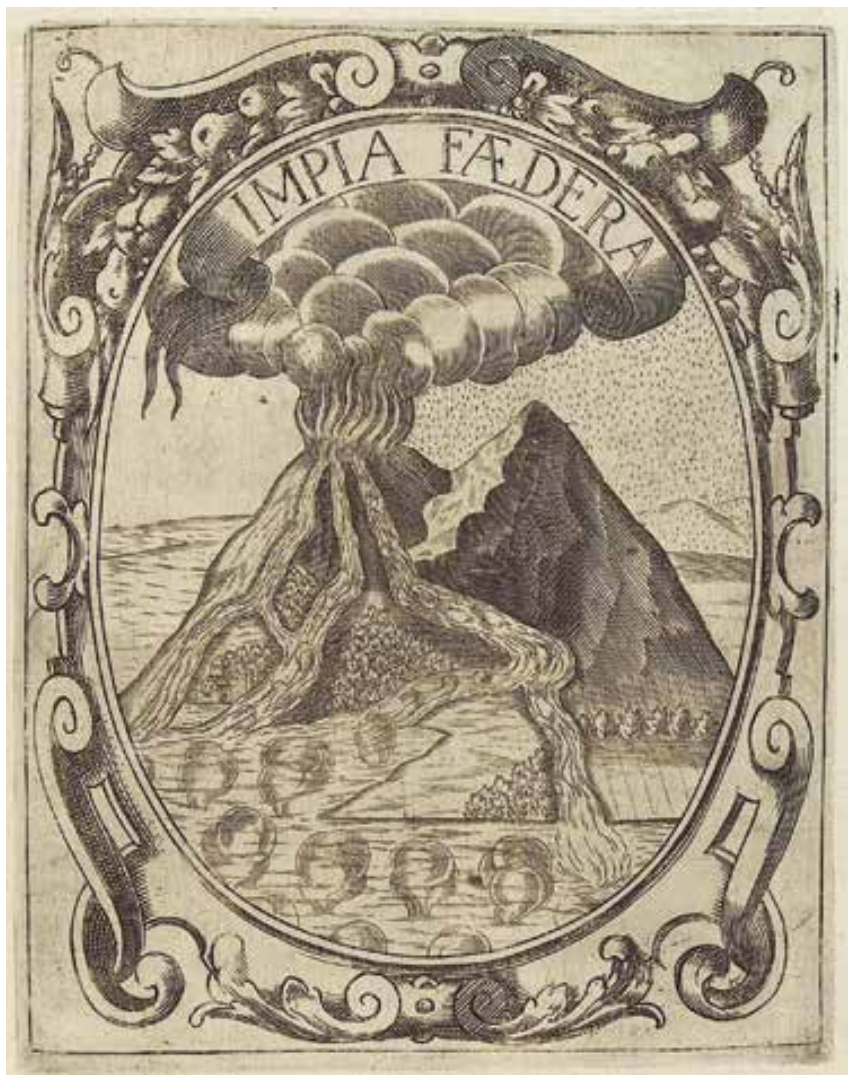

Fig. 24. Impia faedera (Alianzas impías) (1640)

calor» (14-8-1652); y confía en que «aunque se compusieron los de Burdeos, parece que vuelven a titubear con el calor de mi armada que los asiste» (3-91653). Sor María, muy crítica con los franceses, se congratula de sus divisiones internas: «Nunca creí que me había de alegrar tanto de las discordias entre criaturas humanas» (12-2-1649), considerándolas como camino para la paz y admirando los ocultos designios de Dios, «porque no hay azote más severo que el de las discordias domésticas, que todo lo dividen y destruyen» (24-8-1652). Ruega, por tanto, al Señor que «con el aliento de nuestra armada humille a los franceses hasta que se ajusten a la paz» (23-5-1653).

El empeño de Felipe IV por fomentar las discordias surgidas en Francia se relaciona con la empresa Disiuntis viribus (Con las fuerzas disgregadas), cuya imagen presenta un caudaloso río que se divide en múltiples riachuelos, cada vez menos vigorosos [Fig. 25]; así, para aniquilar a una potencia enemiga, 


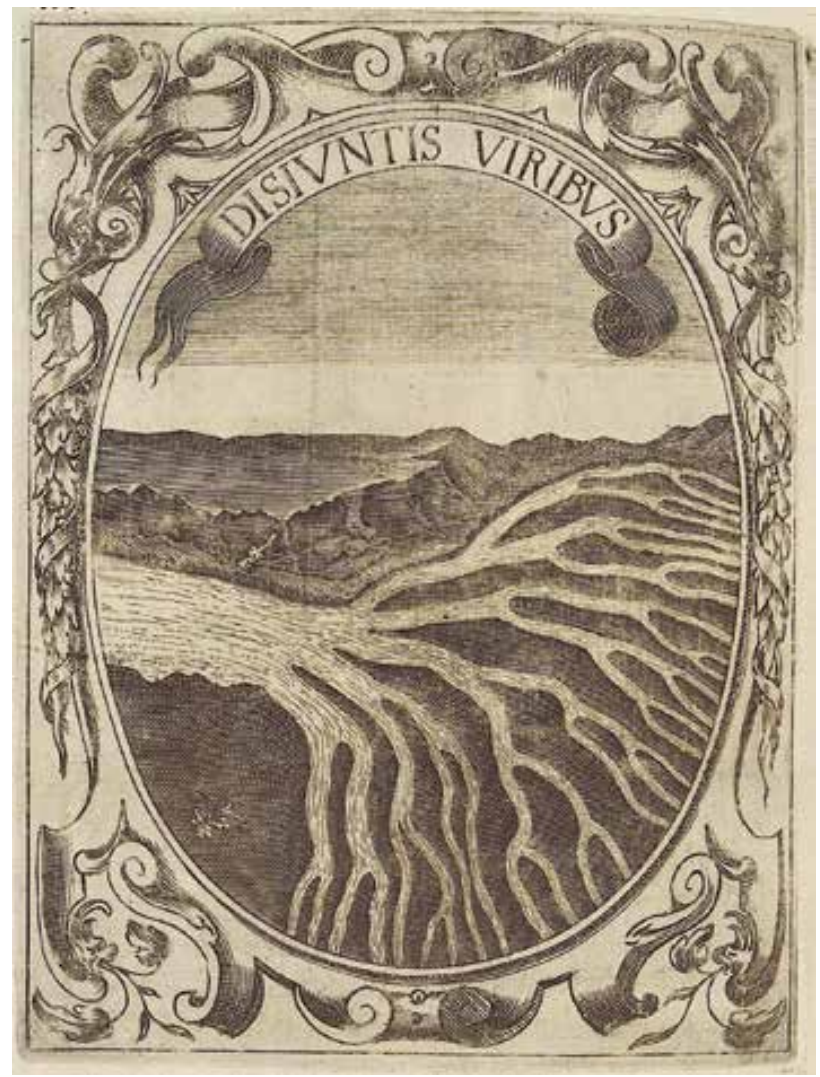

Fig. 25. Disiunctis viribus (Con las fuerzas disgregadas) (1640)

conviene aprender a sembrar la división en su seno. Saavedra admite la oportunidad de introducir cierto tipo de discordia en los reinos sacudidos por las sediciones internas, para dividir las facciones y debilitar las fuerzas del enemigo; pero tal maniobra solo es admisible en el contexto de una guerra, pues lo contrario resultaría «indigna acción de un príncipe vencer al otro con el veneno y no con la espada». La situación de guerra hispano-francesa justificaba plenamente esta táctica. ${ }^{57}$

57. De hecho, el propio Saavedra había tenido oportunidad de comprobar la eficacia del sistema propagandístico a la hora de sembrar la discordia como autor de varios libelos escritos para «turbar a Francia», sirviéndose de una acumulación de argumentos que revolviesen las filas francesas y frenaran la guerra contra España. MARÍA SOLEDAD ARREDONDO: «La espada y la pluma contra Francia en el siglo XVII: cartas de Quevedo y Saavedra Fajardo», Criticón, n. ${ }^{\circ}$ 56, 1992, pp. 106-107; y Christian Bouzy: «Diego de Saavedra Fajardo o el diplomático panfletario: una visión española de la paz», Empresas políticas, n. ${ }^{\circ}$ 9, 2007, pp. 109-114. 


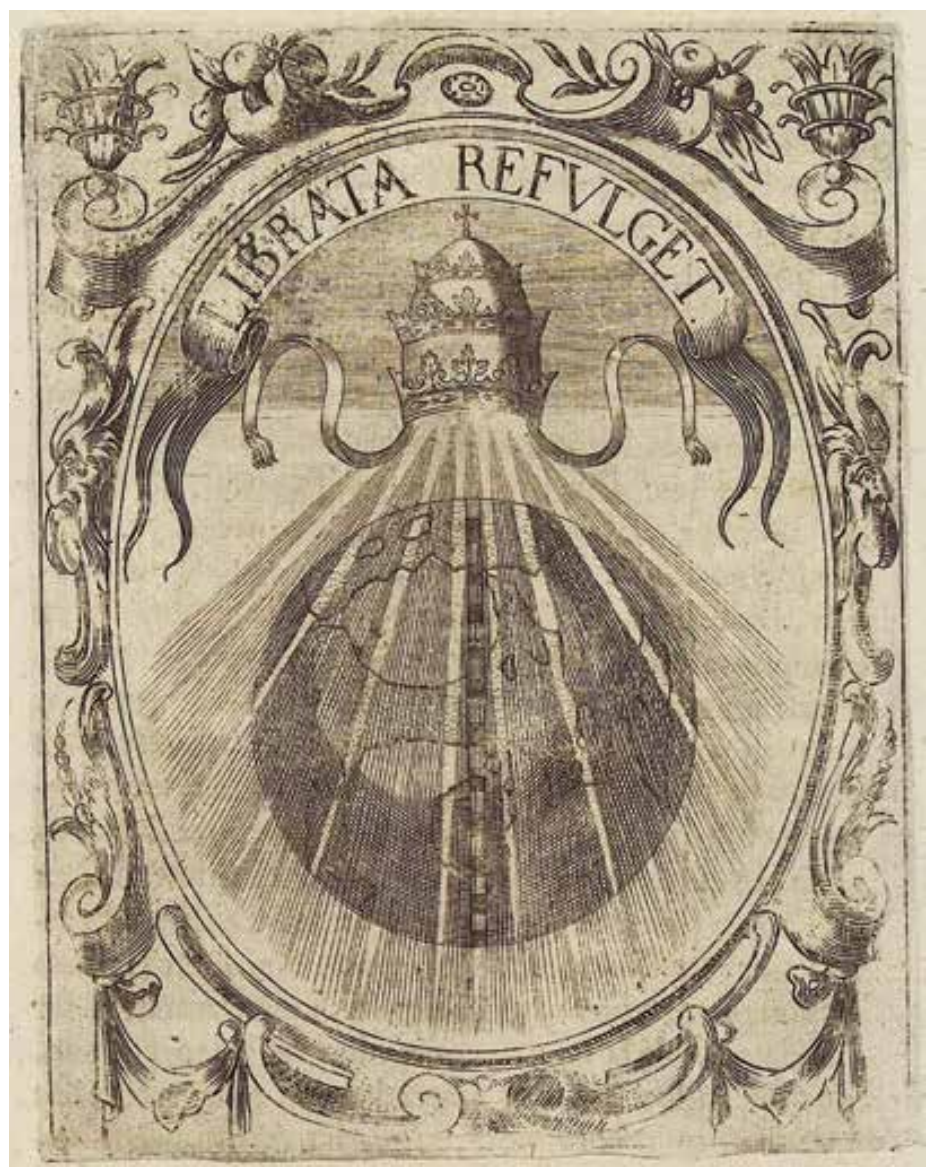

Fig. 26. Librata refulget (Resplandece equilibradamente) (1640)

En la búsqueda de la paz entre España y Francia, el papa desempeña un papel fundamental, pues a él corresponde actuar como árbitro que dirima los conflictos entre príncipes cristianos, tal y como recoge Saavedra en su empresa Librata refulget (Resplandece equilibradamente), en la que mediante una tiara pontificia que a modo de sol desprende rayos sobre la esfera terrestre [Fig. 26] simboliza al papa que, como Sol de Justicia, envía su luz sobre todas las provincias del mundo y mantiene la quietud entre los príncipes de la cristiandad. El anhelo de paz con Francia llevó a sor María a escribir en 1658 a Alejandro VII solicitando su intervención, de manera que «interponga su autoridad de sucesor de Cristo y compela a los príncipes cristianos a que hagan 
paces, si no quiere ver en su Iglesia grandes trabajos». ${ }^{58}$ En su respuesta, el pontífice parecía adquirir tal compromiso al rogar a la religiosa que «dispusiese los corazones de los príncipes para que sus diligencias tuviesen ejecución»; por tal motivo, sor María preguntaba meses más tarde a Felipe IV «si el Pontífice nos ayuda a las paces» (14-3-1659). Pero el monarca, que ya años atrás había manifestado su escepticismo acerca de la mediación papal al denunciar que «su cabeza atiende más a materias de Estado que a lo que debe hacer» (9-11647), la desengaña al observar que «no toma este negocio tan a pecho como es su santo ministerio» (24-3-1659). Casi llega a justificar tal comportamiento al afirmar que la intervención papal no resulta sencilla, pues si bien «como cabeza de la Iglesia le toca corregirnos y castigar con sus armas, estas materias políticas y de estado pueden mucho, aún con el Vicario de Cristo» (21-4-1659). Es decir, Felipe IV coincide con Saavedra al reconocer la autoridad del arbitraje papal, aunque en última instancia y ante la escasa implicación de este decidirá actuar por su cuenta, enviando un agente con proposiciones de paz y la oferta de la mano de su hija para Luis XIV. Sor María no pudo ocultar su decepción al confesar que «es justa queja la de V. M. de que Su Santidad no haya ayudado a las paces» (29-5-1659).

Una última cuestión en materia de política militar nos lleva a considerar que tan importantes como las armas resultan los recursos económicos para asegurar la defensa de los reinos. Felipe IV es consciente de que ambos son los dos pilares fundamentales para la paz de la monarquía; de ahí sus continuos lamentos ante «el corto caudal que no alcanza para nuestra defensa» (6-111645), que con expresiones similares se repiten a lo largo de todo el epistolario. En este punto, sor María insiste en que «se excusen los gastos superfluos» (196-1649) en beneficio de la provisión de las plazas y ejércitos, aconsejando al monarca que «no consienta haya excesivos gastos en las fiestas cuando falta el caudal para defender la Corona» (20-4-1658). Felipe IV está de acuerdo con la religiosa en su propuesta de reducir los costes de regocijos, comprometiéndose a «ejecutarla en cuanto me fuere posible» (29-4-1658). Tales reflexiones encuentran su eco en la empresa Ferro et auro (Con hierro y con oro), cuya pictura muestra una mano que se posa sobre un orbe terrestre sujetando a la vez una espada y un ramo dorado [Fig. 27]; para Saavedra, el mundo se gobierna con las armas y las riquezas, que tienen mutua dependencia, por cuanto «el dinero es el nervio de la guerra». De la economía depende la conservación de la monarquía, afirma el diplomático, quien coincide plenamente con sor María en la necesidad de moderar los gastos superfluos de la corte, por cuanto «la verdadera grandeza no está en lo que se gasta en las fiestas públicas, sino en tener bien presidiadas las fortalezas y mantenidos los ejércitos». 


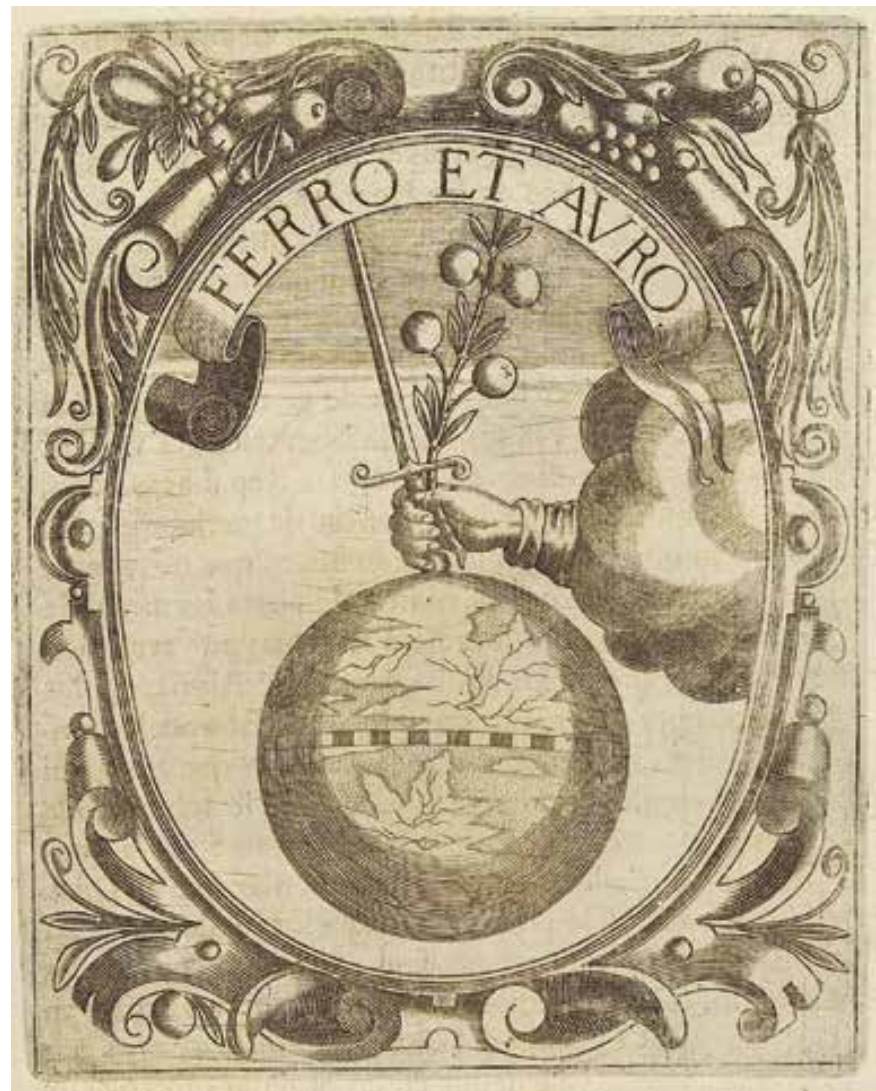

Fig. 27. Ferro et auro (Con hierro y con oro) (1640)

Todavía en clave económico-militar, Felipe IV es consciente de la importancia de la navegación para asegurar el dominio de la monarquía; así queda de manifiesto a lo largo de todo el epistolario, al tratarse de un tema del que mantiene permanentemente informada a sor María y le pide una y otra vez que encomiende al Señor el buen suceso de flotas y galeones, sobre todo los procedentes de Indias. ${ }^{59}$ La religiosa coincide con el rey en la necesidad de lograr la hegemonía naval, asegurando que «por ella ha de venir el mayor socorro de España» (6-7-1657). También en Saavedra la política marítima ocupa un destacado lugar, consciente de que «nuestro poder está pendiente de los arbitrios de los vientos y de las olas», y de que la falta de dominio naval aleja

59. Así se comprueba en las cartas de 29-12-1643, 8-7-1645, 16-8-1645, 15-5-1647, 27-7-1650, 2-71654, 22-7-1654, 18-8-1655, 1-8-1656, 29-8-1656, 30-12-1656, 13-3-1657, 18-4-1657, 25-6-1657, 10-2-1659 y 21-4-1659. 


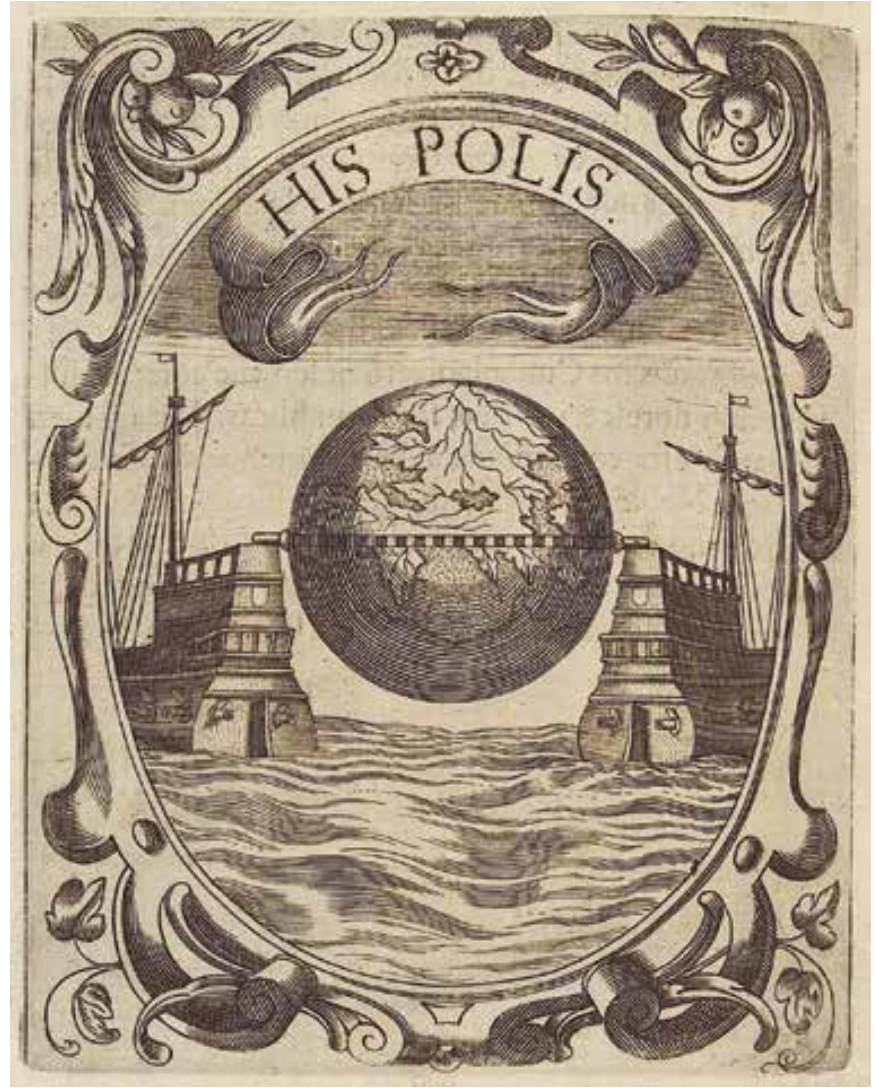

Fig. 28. His polis (Con estos polos) (1640)

a España de los dos ejes de su grandeza, el Mediterráneo y el Atlántico. A este tema dedica su empresa His polis (Con estos polos), que muestra a dos barcos sujetando con sus popas un eje que atraviesa de polo a polo un gran globo terrestre, dando a entender que «es la navegación la que sustenta la tierra con el comercio y la que afirma sus dominios con las armas» [Fig. 28]; a través de la misma exhorta al príncipe a fundar su poder «en las armas navales, si quisiere aspirar al dominio universal», pues quien domine el mar podrá decir que es «árbitro de la tierra». ${ }^{60}$

60. Sobre la importancia que concede Saavedra al dominio del mar en el sistema de poderes, véase LuIS Martínez-Agulló: «Saavedra Fajardo y Europa», Revista de Estudios Políticos, n.o 161, 1968, pp. 103-105; PLGB: «Saavedra Fajardo y la política marítima de España», Empresas políticas, n. 7, 2006, 133-137; y Rogelio Fernández Delgado, «La emblemática y el pensamiento económico español», pp. 60-61. 


\section{CONCLUSIÓN}

La lectura de las cartas de Felipe IV describe a un monarca que actuó conscientemente como príncipe político-cristiano durante la mayor parte de su vida. Sin duda, a ello debieron contribuir tanto su relación epistolar con sor María de Ágreda, como la doctrina vertida por Saavedra Fajardo en sus Empresas políticas.

Sor María sintetiza su concepto del gobernante perfecto al referir a Felipe IV que «es dichosa la Monarquía que alcanza un príncipe heroico en virtudes, observante en la religión cristiana, puro en su doctrina, amador de la verdad católica, celoso en obras pías, templado en sus pasiones, fuerte y magnánimo, prudente en su valor; mostrándole en quitar de su república los daños generales, en administrar justicia sin exención, oyendo a los más sabios y cursados en la ley» (18-2-1650). Todo ello lleva a C. Seco a concluir, acerca de la dirección espiritual de la religiosa, que «su empeño era tallar en su augusto confidente la imagen ideal del príncipe cristiano». ${ }^{61}$

Por su parte, como observa S. López Poza, ya el propio título de la obra de Saavedra -Idea de un principe politico christiano- anuncia que lo que se presenta es un diseño de príncipe modélico, según los preceptos de la complicada política de los nuevos estados, pero sin olvidar los principios cristianos que le obligan a considerar la ética y filosofía moral. ${ }^{62}$ Cartas y Empresas van encaminadas en última instancia a un mismo fin; de ahí que los consejos dados desde la silenciosa celda del monasterio soriano, o desde la dilatada experiencia que otorga el conocimiento de «las cortes más principales de Europa», sean en muchas ocasiones coincidentes; y que tanto unos como otros resulten claves a la hora de modelar la imagen del príncipe que desde el providencialismo divino debe pilotar la nave de la monarquía española.

61. Epistolario español, vol. IV, p. LX.

62. SaAVEdra Fajardo, Empresas políticas, p. 41. 